\title{
Fra et sønderjysk arbejderhjem
}

\section{Af Anders Johnsen}

Jeg blev den sjette i rækken af Anders Hansen Johnsen og Marie Lousens børn. Efter sigende var min fødedag en smuk efterårsdag. Min mor havde været $\mathrm{i}$ kartoffelmarken for at samle kartofler helt til mørket faldt på og ved 22-tiden skænkede hun mig livet. Der er fortalt, at det var en stor knægt, mor fødte, i nærheden af de 10 pund. Mor har ved en lejlighed fortalt, at det at føde børn regnede hun ikke på. Det blev hurtig overstået, så det voldte hende aldrig bekymring forud for en forestående fødsel. Mor fødte otte børn i løbet af knap fjorten år, dertil yderligere nogle aborter, så mors påstand har nok varet rigtig.

Far traskede dagen efter min fødsel til Der Standesbeamte i Strandelhjørn, for at jeg på behørig vis kunne blive indført $\mathrm{i}$ journalen, som loven påbød, i rækken af kejserens undersåtter. Jeg blev indført $i$ protokollen med fornavnene Anders Marius. Anders var efter min far, Marius efter min mor. Det kunne jo udmærket gå med sådan en lille omskrivning fra Marie til Marius, og da meningen nok har været, hvis det ellers ville føje sig, at jeg skulle være rosinen i pølseenden, ja så var det $\mathrm{da}$ en meget fornuftig beslutning. Jeg blev nu ikke den sidste $\mathrm{i}$ rækken, men det er en hel anden sag.

\section{Min far og mor}

Min far var født på Østerby kro i Daler sogn i 1873 som søn af kromand Nis Johnsen og hustru Ane født Schmidt fra Emmerlev. Far mistede tidlig sin mor og blev i 1881 sat i pleje hos gårdmand Nis Johnsen, en fætter til hans far. Efter konfirmationen kom far $i$ urmagerlære i Højer. Efter udstået læretid gik han på valsen, som skik var for datidens hændværksvende. Far endte nede i Westfalen, nærmere betegnet i Osnabrück, hvor han var i længere tid. Derefter var han i Hamborg og endte med et kortere ophold i Danmark. Under et beseg i Nr. Hostrup, hvor min fars bror Martin Johnsen var lærer, lærte min far min mor Marie Lousen at kende. Dette førte til, at de indgik ægteskab i Agerskov kirke i året 1900. Min mor var datter af Peder Hansen Lousens andet ægteskab med Bertha Nielsen fra Rise ved Rødekro. Mor var født i Rangstrupgårde i 1873, så far og mor var jævnaldrende. 
Mor havde fra barnsben en legemlig skavank, idet hun var skæv i overkroppen. Dette havde dog ingen indflydelse på hendes vitalitet, den var der ikke noget $i$ vejen med. Efter giftermålet bosatte de sig $i$ Gammelskov i Agerskov sogn. Far tog arbejde som arbejdsmand og daglejer med urmagerfaget som bibeskæftigelse. Her i Gammelskov »i æ Pottehus « - navnet havde det fået efter en pottemand, som havde beboet huset - fødtes de fem af mine søskende, som var forud for mig.

Det var drøje år for mine forældre. Far har fortalt, at han som daglejer om vinteren har stået $\mathrm{i}$ loen og tærsket med plejl for 50 penning om dagen og dertil en liter mælk, men vel at mærke på egen kost. Foråret og sommeren var fortjenesten bedre, da kunne der tjenes op til 2 til 3 mark ved tørvegravning og høslet; men arbejdstiden var heller ikke under 10 timer, til tider mere.

For mor var det ejheller en dans på rosenblade, tornene fulgte med. Familien blev forøget med et nyt medlem hvert år.

Æ kehl (brønden) ved huset gav ikke vand nok til daglig behov, så til tider måtte vand til husholdning og vask hentes $\mathrm{i}$ et vandhul ca. 50 meter fra huset. Det kunne om vinteren være brydsomt, når sne og frost indfandt sig. Mine forældre har fortalt, at det daglige brød altid var $i$ huset. Fra anden side har jeg ladet mig fortælle, at min mor kunne lave god og nærende mad af den pind, kragen hvilede på. Det er nok overdreven snak. Jeg har senere erfaret, at mor kunne lave meget af lidet. Det var ganske nødvendigt, for at de kontanter, far hjembragte, blev forvaltet, så det hele kunne løbe rundt.

\section{Fra Gammelskov over Hyrup til Neder-Jerstal}

I 1908 flyttede familien fra Pottehuset til Hyrup i Bevtoft sogn. Forinden var to af mine søskende afgået ved døden og hver fået en lille grav i det sydvestlige hjørne af Agerskov kirkegård. Far havde i Hyrup købt et kådnersted. Så vidt jeg af tingbogen har kunnet se, var købet pro forma, den virkelige ejer var en gårdslagter. Far havde jo ingen kontanter, kautionen han stillede var hans arbejdskraft. Jorden var af dårlig bonitet, så det har næppe kunnet give det daglige brød. Det var på dette kådnersted, jeg kom til verden i 1909 og en søster i 1911.

Efter fire år i Hyrup skiftede vi igen bosted. Far fik arbejde som banearbejder ved $\mathfrak{a}$ lillebahn og købte et lille hus i Neder-Jerstal, denne gang ved hjælp fra Agerskov sogns spare- og lånekasse med min morfar som kautionist.

Mine brødre, der var skolepligtige, har fortalt, at fraflytningen fra 


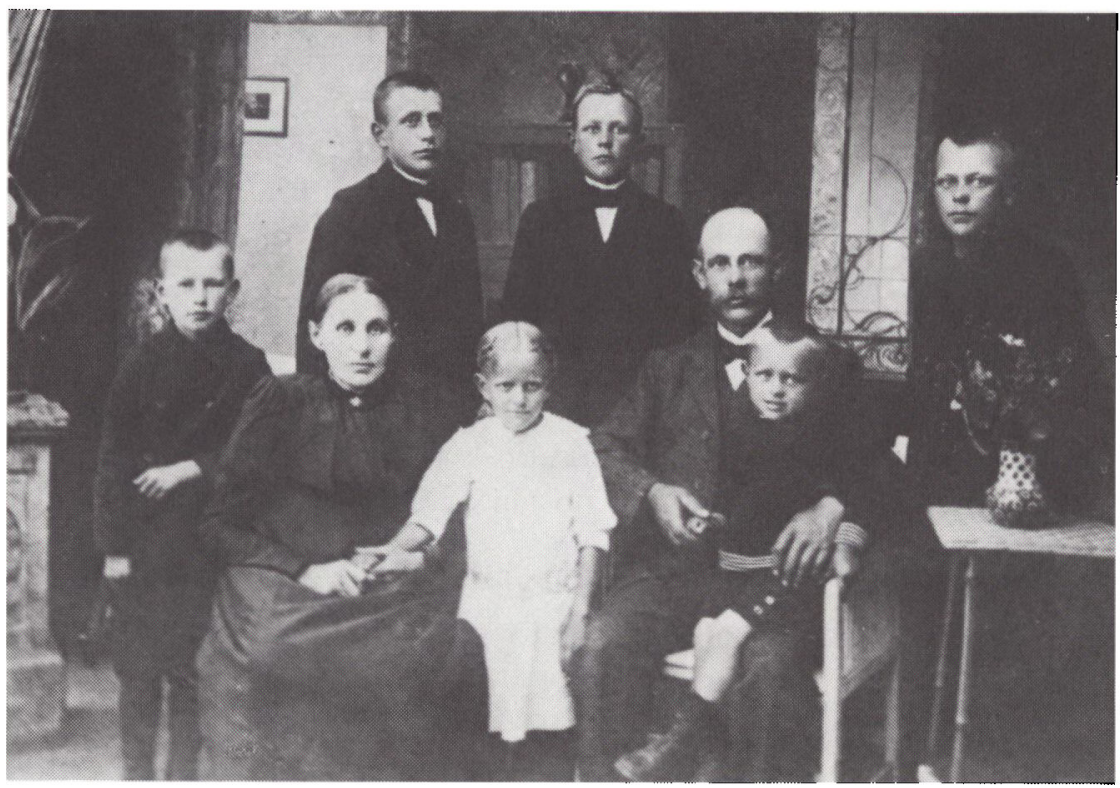

Familien Johnsen. Foto fra Christiansfeld 1917. Forfatteren ses yderst til venstre.

Hyrup skete ret hovedkulds, ja, så hurtig, at de om formiddagen blev hentet ud af skolestuen, og inden aften var hele familien installeret $\mathrm{i}$ Neder-Jerstal. Det var ikke nødvendigt med et flyttefirma, hele bohavet kunne være på en kassevogn. Hvad angår størrelse og miljø lignede Hyrup og Neder-Jerstal meget hinanden. Dog havde Neder-Jerstal fået en ny. skole. Hyrup og Neder-Jerstal havde også det til fælles, at horisonten altid kunne ses. Beplantning var der ikke meget af, nogle træer og buske ved gårdene og husene var en regel, dog var Hjartbro skov og Bevtoft plantage inden for synsfelt. Der var stadig hedestrækninger blandt andet ved Jægerlund, derfra var frit udsyn helt til OverJerstal.

Neder-Jerstal by var delt på langs og tværs. På langs af landevejen Haderslev-Tønder, de nærmeste lokaliteter på denne i øst og vest var Over-Jerstal og Galsted. På tværs syd og nord Træhede og Bevtoft plantage. Denne vej var nærmest kun et sandet hjulspor og krydsede landevejen midt $\mathrm{i}$ byen.

En skillelinie var også Sønderå nu kaldet Gelså, som havde sit løb umiddelbart vest for krydset. Her blev byen forbunden med den store 
bro, som vi kaldte den. Af gårde med større tilliggende var der kun Peter Holm og Johanne Linnings gårde. De lå på hver sin side af vejen efter Bevtoft plantage. En ejendom tilhørende Anton Gøeg var nabo til Peter Holm og den sidste på vejen mod plantagen. Endnu en gård på samme side, men nærmest krydset var Johansens gård. Gården var dog nedlagt, idet Peter Holm havde købt den samt jordtilliggende. Gårdens stuehus blev under krigen benyttet som indkvarteringssted for tyske soldater og efter krigen som bolig for Peter Holms malkerøgtere. Nærmest Johansens gård på hjørnet ud mod landevejen lå et nedlagt ovnhus. Det blev under krigen benyttet af det tyske militær, som her havde smedie. Ellers var dets funktion kun at være hjemsted for $» Æ$ Kasten«. Den var placeret på porten, og bekendtgørelser fra Der Standesbeamte var ophængt her. En af dens vigtigste funktioner var, at lysning til ægteskab i sognet blev foretaget her. Man sagde, at det kommende brudepar var "ophængt i æ kasten«, og meningen blev aldrig misforstået. De fleste holdt dog fast ved den gamle skik også at få lysning fra prædikestolen.

Handlingen i kirken blev altid betragtet som det rigtige, der gjorde dem til rette agtefolk at være. Det andet var påtvungen og noget man skulle tage med. $\mathbb{E}$ kasten fungerede til dansk administration blev indført i 1920.

På vejen mod Træhede, mellem vejen og åen lå Anton Jacobsens gård (nu nedbrændt). Den havde i sin tid været Neder-Jerstals kro; men krostuen var forlængst nedlagt. Længere fremme på vejen og på samme side, lå et par husmandssteder, tilhørende henholdsvis Ingward Gram og Lauritz Rudebeck. Sidstnæuntes far var Nis Rudebeck. Han var skovfoged over Bevtoft plantage, og vi børn syntes, det var et herligt skue, når han i sin grønne uniform red til skovs på sin pony.

På modsat side, over for Anton Jacobsens gård lå den gamle skole, som var nedlagt som skole i $1912 \mathrm{og}$ nu blev beboet af bygmester Nis Sandholdt. Længere fremme var et lille vejstykke mod sydøst. Her lå den stationsbygning, som var bygget i 1904, da æ lillebahn blev anlagt. På samme vejstykke lå også et lille jordløst hus tilhørende Nis Jensen.

Ved landevejen, når man kom fra Over-Jerstal, var der ingen bebyggelse på højre side. På venstre side var det første, man mødte, den ny skole, som var bygget i 1912. Derefter det lille hus med tegltag, som min far havde købt, og nabo til os et aftægtshus tilhørende Rasmus Jepsen. Han var svigerfar til Peter Holm. Efter broen over ån delte vejen sig med en retning mod Galsted og en retning mod Bevtoft. Dér, hvor vejen delte sig, $\mathrm{i}$ trekanten, lå et meget gammelt stråtækt hus. Her 
boede gamle Thie Midtgaard. På vejen efter Galsted lå én landejendom tilhørende Heiselberg.

På vejen efter Bevtoft på højre vejside lå også et lille stråtækt hus, ejet af banearbejder Ludwig Bahr. Lidt længere fremme på samme vejside sluttede byen med et lille stråtækt hus, som blev beboet af rentier Andreas Topp. Dette hus blev i $1917 \mathrm{købt}$ af min far, og blev i nogle år bolig for min morfar Peder Lousen. Ja, så skal også nævnes Peter Vodders gård på venstre vejside; men så er også hele byen placeret, og stort set holdt Neder-Jerstal sit udseende uforandret helt indtil anden verdenskrigs afslutning. Da æ lillebahn Haderslev-Ustrup-Over-Jerstal-Toftlund blev åbnet for trafik i 1904, var det vel ventet, at NederJerstal skulle få en vis udvikling. Det skete ikke. Det eneste, man fik, var en stationsbygning. Banen var dog et stort gode. Egnens befolkning fik lettere adgang til omverden både til øst og vest; især muligheden for at komme til købstaden Haderslev var nu stærkt forbedret. $Æ$ lillebahn har ikke fået det eftermæle, den faktisk fortjente. Det var et stort fremskridt i samfærdsel, da den blev anlagt.

\section{Neder-Jerstals omegn}

I begyndelsen af vort århundrede var megen hedejord kommet under plov; men meget var endnu tilbage. Plantningen af Bevtoft plantage var påbegyndt omkring 1850; men i det store og hele var horisonten stadig $\mathrm{i}$ det fjerne. Nyt håb og virketrang kom tilbage ved genforeningen med Danmark i 1920.

En ny generation kom på efterskole og højskole. De vendte hjem med nye tanker og ideer, der blev omsat $i$ handling. Da det mest var landboungdom, der frekventerede disse skoler, var det også dem, der blev førende med initiativ og foretagsomhed. Et initiativ var plantning. Der blev plantet meget i Sønderjylland. Neder-Jerstals omegn var ingen undtagelse. Her blev plantet granplantage af anseelig størrelse. Jordens beskaffenhed var velegnet, hele landskabet blev forandret til det bedre, horisonten blev indskrænket. Det hele blev ikke mere så barsk. Nu 60 år efter genforeningen er Agerskov og Bevtoft sogne, ja, hele Nordslesvig en skøn og ydedygtig landsdel af det danske rige.

En foregangsmand på plantningens område var gårdejer Peter Riis i Jægerlund. Han satte sig et varigt minde ved at tilplante ca. 10 ha. af sin hedejord med gran. Hedeselskabet benyttede senere Peter Riis erfaring, da der blev tilplantet et større område ud efter Træhede. Dem, der kun 
har set Neder-Jerstals omegn for 60 år siden, vil ikke kunne kende den idag.

\section{Hus og have}

Familien bestod af syv medlemmer, da vi flyttede ind i Neder-Jerstal. Kort tid efter måtte der også skaffes plads til min morfar, så hvad angår pladsforhold, var vi så at sige kommet fra asken $i$ ilden. Pladsforholdene i Hyrup havde været bedre; men efter mors udsagn var hun tilfreds med byttet. Hun fik mere tid til at passe familien. Der blev lidt mere albuerum, da mine to ældste brødre fik plads som tjenestedrenge hos et par bønder i omegnen. Lønnen var mindre end minimal; men der var vel også en grænse for, hvad drenge omkring de ti år kunne præstere af arbejdskraft. Kost og logi var en del af lønnen, så det hjalp på den daglige økonomi og pladsforholdene $\mathrm{i}$ hjemmet. Tænker man tilbage, så var det jo strengt, at drenge omkring de ti år skulle hjemmefra for at tjene det daglige brød. Tidligt op om morgenen, være til hjælp i stald, før turen gik til skole. Efter hjemkomsten fra skole arbejde $\mathrm{i}$ mark og lade, om aftenen lektielæsning, når øjnene kunne holde sig åbne. Leg blev der ikke tid til. Sådan var vilkårene for mange småkårsbørn. Den almindelige opfattelse var - bortset fra de undtagelser, som der virkelig også kunne være - at havde et ægtepar anskaffet sig børn - i far og mors tilfælde var det otte i antal - så havde de selv været ude om det, så var det deres egen sag, at skaffe dem føde og klæder og få dem i vej, herunder selv at betale de nødvendige rekvisitter til brug i skolen. En tavle og griffel, en bibelhistorie, katekismus, læsebog, geografibog og en regnebog. Det var, hvad man havde brug for i skolen på landet; men det kunne også tynge på et budget i et arbejderhjem. Dengang skiftede man ikke så ofte lærebøger, de kunne gå $\mathrm{i}$ arv. Genbrug er ikke en ny opfindelse, bøgerne blev virkelig slidt op.

Neder-Jerstals stolthed var den ny skole. Skolen var en pæn rødstensbygning, bygget af bygmester Nansen fra Tirslund i 1912. Skolens grund var ret stor. Der var legeplads, og uden om denne og skolen var plantet læhegn, så det efterhånden fik et venligt udseende. Vi blev nabo til skolen, da min far i 1912 købte det lille hus, der havde skel ind til skolens grund. Huset var bygget i 1887. Det var altså 25 år gammel, da vi flyttede ind. Huset var et såkaldt »brændevinshus«. Det skal forstås på den måde, at det var bygget ved hjælp af naboer og gode venner. Daglønnen var den brændevin, man kunne tylle i sig i 
arbejdstiden. Tilsyneladende har de våde varer ikke haft indflydelse på vinkel og øjemål, og huset har da også modstået tidernes omskiftelse.

Der var ikke mange offentlige myndigheder, der blandede sig, når det var godkendt af Feuerwehrhauptmann, og her var det vigtigste, at skorstenen havde de befalede mål, at der uden for huset var anbragt en let tilgængelig brandstige, $\mathrm{ja}$, så var alt $\mathrm{i}$ orden og grundbogen fik ejerens navn og adresse. Huset var bygget med tegltag. Havde det været med stråtag skulle der også uden for huset være anbragt en brandhage. Denne var en lang træstang med en jernhage, der skulle benyttes til nedrivning af stråtaget $\mathrm{i}$ tilfælde af brand. Jo, man kunne klare sig med lidt.

Huset, som vi børn betragter som vort egenlige barndomshjem, har, siden vi rejste derfra, skiftet ejere flere gange, og har gennemgået flere foryngelseskure, så det har ikke megen lighed med det hus, vi rejste fra i 1922.

Ved vor indflytning i 1912 var beboelsesarealet ca. $50 \mathrm{~m}^{2}$. Der var et dørns (stue), for vort vedkommende både opholdsstue, spisestue og til tider også soveplads, idet sofaen var anbragt her. Sofaen agerede også

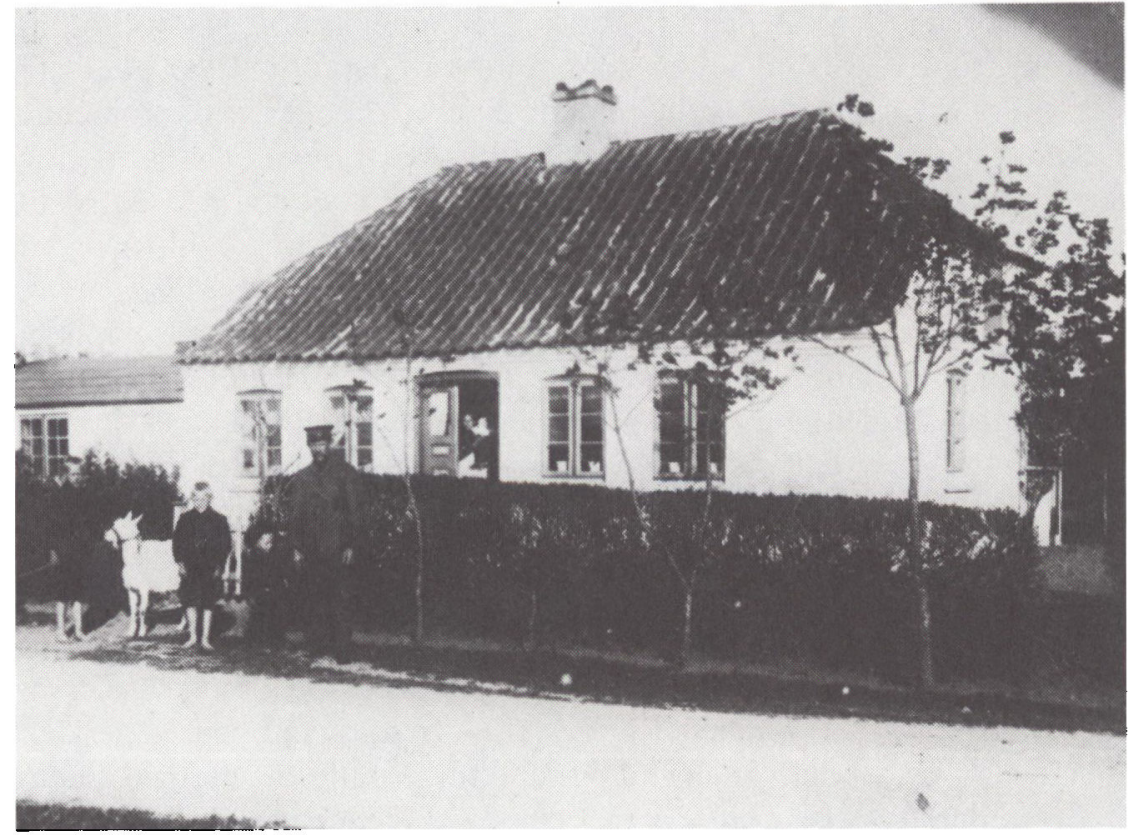

Familien Johnsens hjem $i$ Neder-Jerstal 1913. Forfatteren ses med sin fader ved hånden. 
som seng, når en eller anden af os var syg og skulle være under opsyn eller være anbragt $i$ varmen. Der var et lille sovekammer, et endnu mindre køkken, forstue, spisekammer, endnu et lille kammer med indgang fra køkken. Det var ikke større end et dobbelt klædeskab, her havde vi drenge vor soveplads $i$ en tredobbelt seng, som far havde tømret sammen. "Klædeskabet« havde et staldvindue af jern. Det kunne ikke åbnes, så luften og duften var lidt blandet, når nattens søvn og hvile var overstået. Så var der endnu et lille kammer med indgang fra køkken, her boede min morfar et års tid, her var plads til en seng, en stol og hans chatol; men dermed var også hvert hjørne i huset belagt.

I den østre ende af huset var der udhus. Her var tørvelade, plads til et par geder og nogle høns og så det nødvendige wc. Det var nu ikke en betegnelse, vi kendte dengang. Det blev kaldt $æ$ vandhus. Det bestod af et lille aflukke med et vandret brædt, hvorunder der var anbragt en spand, hvis indhold blev tømt ud i møddingen. Når efteråret kom, blev det kørt ud på havejorden sammen med den gødning, der var skabt af høns og geder og den gris, der trods kneben plads også var fundet et hjørne til. Med udgang fra køkkenet var der et vaskehus, bygget op af bræddevæg med paptag over. Her var gruekedlen og de nødvendige remedier m.m. anbragt. Her i dette rum, hvis man ellers kan kalde det sådan, foregik den daglige kropvask. Det var ikke just behageligt, at opholde sig i vaskerummet en kold vintermorgen, så det var om at få det overstået så hurtigt som muligt. For vi drenges vedkommende nærmest en symbolsk handling omkring næsetippen. Det skal dog siges, at det ikke altid blev godtaget af vor mor. Før vi tog afsted til skole, måtte vi stille til parade. Ørerne blev kontrolleret, neglene ligeså - bevar mig vel - det kunne til tider være en højest nødvendig kontrol. Tandbørste kendte vi ikke dengang, så der havde vi da ikke tidsspilde.

En gang om måneden måtte hele vor krop gennemgå en renselsesproces. I dagens anledning var der fyret op under gruekedlen, så der var varmt vand; men det var også den eneste formildende omstændighed. Handlingen foregik i skoldekaret, og der blev skrubbet med brun sæbe, når det ellers kunne fremskaffes, så når processen var overstået var ens overflade som en kogt krebs. Mor havde også den opfattelse, at badet skulle afsluttes med en strøm af koldt vand ned over vor syndige krop. Vi syntes, det var en barbarisk handling over for hendes eget afkom; men mor havde i »Hjemmets Raadgiver « - en af de få bøger vi havde i hjemmet - lest, at det var en god og sund foranstaltning, dermed basta.

Lige uden for vaskerumsdøren var $æ$ kehl (brønden). Den var ca. 3 meter dyb, overdækket med et træstativ. Der var en vinde med reb og 
håndsving, og på den måde blev vandet firet op i den nedsænkede spand. Til tider kunne det ske, at der kom en hoppaet (frø) med op i den fyldte spand. Den var faldet ned mellem de utætte brædder.

Omkring huset var der en temmelig stor have. Foran, ud mod $æ$ skasè (landevej) var den køn kalgård (have) skærmet af en tjørnehæk. Her var der som regel lidt sommerblomster, og op af husmuren var duftende hvide roser. Bag huset var et stort jordstykke, hvor der det ene år efter det andet blev avlet kartofler, så vi havde nok til vinterforbrug. Til tidlig brug havde vi røde kartofler. Det var nogle gevaldige knolde, navnet på sorten husker jeg ikke. Vest for huset havde vi nogle højstammede æble- og pæretræer, og her var også en stor rødtjørn, som i blomstringstiden var et skønt skue. Mod syd og nærmest brønden havde vi solbær, stikkelsbær og ribs, sidstnævnte blev kaldt hansbær. Der var også plads til sommersalat, er herlig spise, der blev serveret $\mathrm{i}$ kærnemælk. Der var rødbeder, gulerødder, grønkål og ikke at forglemme kyrbis (græskar). Sidstnævnte og rødbeder blev syltet ned i store brune krukker, så der var nok til hele vinteren. Kålrabi avlede vi ikke. Dem kunne vi få nok af og tilmed gratis hos en bondemand. Vi har aldrig haft jordbær $\mathrm{i}$ haven. Til dyrkning var de faktisk ukendt på egnen, jeg kan ikke mindes, at nogen havde dem i haven. Jeg glemte nok bønnerne, de var også en vigtig bestanddel af vor vinterkost. De grønne bønner blev saltet ned, og om sommeren fik vi gule voksbønner, så det var vitaminer $\mathrm{i}$ lange baner, jo haven var en god hjælper til at mætte en stor familie.

\section{Så fik vi en lillebror}

De to første år i Neder-Jerstal står kun svagt i min erindring, men dagen den 8 . juli 1914 står for mig så tydelig, som om det var $i$ går. Det var en skøn højsommerdag, og den dag fik vi en lillebror, som i dåben fik navnet Christian. Han havde hen mod aften varskoet mor om, at han ønskede at træde ind $\mathrm{i}$ verden. Vi hjemmeværende søskende var derfor i god tid, før storken og jordemoder madam Schmidt arriverede, blevet anbragt hos gamle Thie, som boede i et lille hus, hvor vejen efter Galsted og Bevtoft deltes. Ventetiden tilbragtes udendørs i den lune sommeraften. Den lillebror lod vente på sig, og det blev over vor normale sengetid. Thie begyndte at snakke om, at vi nok hellere måtte gå til sengs; men det passede nu ikke ind i mit kram. Jeg skulle ikke sove i Thies indelukkede alkover, hvis jeg på en eller anden måde kunne undgå det. Heldet var med mig. Ved 22-tiden kom far gående over det, 
vi kaldte den store bro, og jeg løb far henrykt imøde. Ved hjemkomsten kan jeg ikke huske at have set den ny bror. Derimod husker jeg tydelig at hele huset lugtede af et eller andet, jeg tror, det var karbol. Det var nok det, jordemoder madam Schmidt havde brugt som desinfektion.

De følgende dage var et liv i vild luksus. Sagen var den, at alle koner fra byen kom på barselvisit. De medbragte alle noget spiseligt. Til mor var der fersksup (hønse eller kødsuppe), eller der blev medbragt en tort (lagkage). Det gamle ordsprog - når det regner på præsten, så drypper det på degnen - kom også til at gælde for os børn i de normale foreskrevne ni dage, mor rekreerede sig i sengen.

Jeg kan tydeligt huske, at en nabokone kom med den flotteste torte, jeg i mit unge liv nogensinde havde set. Jeg overdriver ikke, det er den fulde sandhed. Tortens midterparti var pyntet med rosenblade af farvet marcipan. Der var ringe af chokoladeovertræk, og hele torten var overstrøet med kulørte kreller (små kugler kagepynt). Midt i var der placeret den nydeligste lille stork; den var dog kun af papir. Tortens midterparti blev skåret $i$ en rundkreds, og dette stykke faldt i min turban. At dette skete, skylder jeg nok en tak for til Marie Schmidt, som var den, der sørgede for, at jeg ikke blev snydt. Jeg skylder nok at fortælle, at hun var tilkaldt for at varetage hjemmet i de dage, mor var sengeliggende. Marie Schmidt var en halvgammel jomfru, som havde været nabo til far og mor, medens de boede i »æ Pottehus«. Hun kom jæunligt $\mathrm{i}$ vort hjem, spadserende fra Gammelskov, enten det var sommer eller vinter. Efter besøget gav mor hende som regel 15 penning til en togbillet, så hun kunne køre med toget fra Neder-Jerstal til Galsted. Men hvad gjorde Marie, efter at have sagt farvel og tak og forsikret, at det ikke var nødvendig at følge hende til toget? Hun rundede stationsbygningen og tog bestik efter Galsted og traskede afsted på sine gamle ben. Denne hendes fidus var afsløret; men mor gav hende hvergang de 15 penning og ønskede hende god hjemfart.

Det var et lille sidespring om jomfru Schmidt; men lad mig vende tilbage til barselkaffen. Under konernes snak om dit og dat ved kaffebordet lagde jeg mærke til en ting, som forundrede mig meget, og som jeg måtte have en forklaring på, da gæsterne var gået. Der skete det, at et par af konerne tog om koppens øre med tommel og pegefinger, mens de tre øvrige fingre strittede ud i den bare luft. Min mor havde en acceptabel forklaring på dette fænomen. Det regnedes for at være fint med disse strittende fingre; sådan gjorde fine damer, når de var til teselskab. Mor havde sin viden fra Familie-Journalen; det har konerne nok også haft. Familie-Journalen og almanakken var den tids 
kulturspreder og toneangivende for almuen. Mor mente forøvrigt, at det var lidt skaberi med disse strittende fingre. Jeg ville dog også gerne være fin og øvede mig i kunsten. Det gik også meget godt, men jeg glemte hurtig det fine og vendte snart tilbage til mere normal funktion med at drikke af en kop.

Jo, der skete noget i disse dage. Inderst inde ønskede man, at storken ville gæste vort hjem endnu engang, inden den tog på sin lange rejse til Afrika, ellers ville det jo vare helt til forår, inden den vendte tilbage, og al den herlighed kunne gentages. En forespørgelse hos mor, om der var mulighed for, at storken kom endnu engang hos os, inden den tog på sin lange rejse, blev besvaret med, at det var der ikke. Der var andre i byen, der havde anmodet om dens besøg, og hun var sikker på, at de først skulle have deres ønske opfyldt. Nå, man kunne jo ikke få både i pose og sæk, det slog man sig til tåls med, og jeg har nok ikke været spids nok til at spørge, hvordan børn kom til verden om vinteren, når storken var i Afrika.

Det vil være kendt, at det var skik og brug og hørte med til kirketugten, at barselkonen skulle gå kirkegang efter en fødsel og ikke måtte vise sig uden for hjemmet, før kirkegangen havde fundet sted.

$\mathrm{Nu}$ snakker jeg efter snak, for efterfølgende beretning er ikke i min bevidsthed. Min mor overholdt ikke denne regel og fik af en nabokone at vide, at dette var i strid med god sømmelighed. Mors svar til nabokonen faldt prompte. Hun ville ikke gå kirkegang, medmindre Anders (min far) gennemgik samme ritual. Skulle der en renselse til, og var det en synd, der krævede tilgivelse, at blive gravid og føde et barn, så var det et falles syndefald. Min mors tankegang var vist rigtig nok.

Lillebrors indtræden i verden var en stor begivenhed for os. Han blev den sidste i rækken og godt forkjalnet (forkælet). Efter mors obligatoriske sengehvile var herredagene forbi. Den hvide borddug og nikkelkanden kom atter på deres vante plads.

\section{1. verdenskrig}

Da vi nåede 1. august 1914 indtraf den menneskeskabte katastrofe, 1. verdenskrig begyndte. Jeg havde ikke forståelse for, hvad dette ville komme til at betyde $\mathrm{i}$ tiden fremover, hvilken omvæltning det skulle blive for mange hjem, også i vort sogn og i det lille samfund i NederJerstal. Det første indtryk af krigen fik jeg en af de første dage $i$ august.

På stationen i Neder-Jerstal var samlet hele familier fra byen og omliggende byer og gårde. De var mødt frem for at tage afsked med en 
far, en søn, en ven eller bekendt, som skulle møde på kasernen i Haderslev for at blive iklædt og derfra til fronten. Mange græd, da toget rullede bort fra perronen. Det kunne jeg nu ikke rigtig forstå. Jeg syntes, det var festligt med så mange folk på stationen. Jeg var lykkelig uvidende om, hvad der forestod de følgende år. Min far var i 1914 over 41 år, så i første omgang blev han ikke indkaldt. Senere, i løbet af krigsårene var far et par gangen på session, men blev zurückgestellt. Det skyldtes, at hans arbejdskraft var nødvendig ved banen. Far slap således for krigstjeneste. Var de følgende krigsår ikke behagelige på de hjemlige egne, var det jo for intet at regne, for hvad der skete på krigsskuepladsen, og efterhånden som krigen skred frem med hungersnød $\mathrm{i}$ de store tyske byer.

Da krigen var en kendsgerning, blev der ret hurtig indført rationering for en hel del livsnødvendige varer. Denne rationering blev udvidet, efterhånden som krigen skred frem. På landet klarede vi os dog i det store og hele nogenlunde.

Det, det kom til at knibe med og virkelig var et problem, var at skaffe tøj, især til os børn. Jeg kan huske, at jeg fik en jakke, der var lavet af brændenælder og papir. Det må have været til min fødselsdag i 1917, jeg fik denne kostelige gave. Jeg var meget stolt af denne fine jakke; men den tålte mindre godt at blive benyttet $\mathrm{i}$ regnvejr formedelst papirindlæget.

Under krigen plukkede vi også brændenælder og spergel til vor gris. Den fortærede begge dele med god appetit, og vi fik gode flæskesider, når den i november måned måtte lade livet.

Verdenskrigen med dens sorg ramte også vort lille bysamfund. Der var nogle, der fik bud, at nu var en far eller søn faldet på »ærens mark «. $\mathrm{Ja}$, sådan var budskabet, når sognets præst indfandt sig $\mathrm{i}$ det ramte hjem. Det har sikkert for ham været en svær pligt at bringe dette budskab.

Der gik ikke lang tid efter krigens udbrud, så kom der russiske krigsfanger til vor by. De blev anbragt hos bønder for at udføre arbejde i mark og stald og dermed erstatte dem, der var blevet indkaldt til krigstjeneste. Det var som regel godmodige mænd. De blev i det store og hele behandlet godt, der hvor de blev anbragt. De fleste var meget børnevenlige. De tog ofte del i vores leg. Mange lærte efterhånden en hel del af vort sønderjyske. Nogle af dem nåede ikke hjem til deres fædreland; de fik deres sidste hvilested i Nordslesvigs jord.

En anden kategori af fanger der omkring 1917 kom til vor by, var de såkaldte fæstningsfanger. Det var tyske statsborgere, der på en eller 
anden måde var kommen i unåde hos den tyske militærmagt. De blev stemplet som »Reichsfeinde - Vaterlandslose«. Der kunne være tale om faneflugt, nægtet militærtjeneste eller andet fædrelandsskadeligt.

Disse straffefangers arbejde var at bygge en fæstningslinie, som blev anlagt tværs over Nordslesvig fra Skærbæk i vest til Genner bugt i øst. Der blev på strategiske steder og med passende afstand bygget store bunkers med underjordiske kasematter med plads til mandskab og alt det djævelskab, der er brug for i en krig. Det var hårdt arbejde for disse fanger, fra sol stod op, til sol gik ned. Der blev arbejdet i bagende sol, i kulde og regn. De fik en meget dårlig føde, varierende fra kålrabi og vand, til vand og kålrabi og dertil en humpel tørt brød. Dårligt påklædt var disse fanger også. Dagligt flere kilometers march til og fra fangelejren, det var en umenneskelig behandling.

En afdeling af disse fanger var en tid beskæftiget med at foretage pigtrådsspærring omtrent ud for vore vinduer. Det var vinter, strid blæst og meget koldt. Mor fandt på, at disse hårdt prøvede mennesker skulle have lidt varmt at drikke, så hun kogte et par gange om dagen en stor kedel rugkaffe. Efter en stiltiende aftale med fangevogteren, kom de formiddag og eftermiddag, enkeltvis for at få en varm kaffetår. Det foregik ved vaskerumsdøren; officielt var de aftrådt på naturens vegne. Det gik også meget godt i nogle dage; men en dag dukkede der en befalingsmand op, én med et par ekstra snore på ærmet, og trafikken med kaffeservering blev opdaget. Mor blev indberettet, og kun et par dage efter måtte hun give møde for den civile dommer på Amtsgericht $\mathrm{i}$ Toftlund. Jeg kan endnu se for mig, den morgen mor steg ind $i$ toget for at køre til Toftlund. Retsmødet skal efter sigende have været en hel festforestilling. Min mors tysk var meget mangelfuldt, så mødet i retten skal nok have været interessant, og hun skal nok have gjort sit til, at det ikke blev en kedelig forestilling. Resultatet af retsmødet blev, at mor fik en advarsel, men trods denne advarsel havde hun fået det indtryk, at dommeren havde stor forståelse for hendes handling. Med middagstoget kom mor tilbage, smilende og velfornøjet. Far fik om aftenen, da han kom hjem, udførlig beretning om hvad der var sket i retten. Jeg var tilstede; men jeg mindes kun, at far tilsyneladende var tilfreds med sagens udfald, især det, at dommeren havde været forstående, var et stort plus. Mor var ikke slået ud; hun ville fortsætte med at servere den varme drik. Hun stillede den store blå kaffekedel ud på gruekedlens låg i vaskerummet, et par emaljerede krus sammesteds - selvbetjening -. Mor kom ikke i vaskerummet, når fangerne mødte op, og et påbud om at låse døren var ikke udstedt. 
Jeg vil tro, at arbejdet uden for vort hus varede en fjorten dages tid, måske mere; det husker jeg ikke nøje. Jeg er sikker på, at disse fanger var mor meget taknemlig, men havde ikke mulighed for at vise det.

Under krigen bestod kaffen af brændt rug. Det var en af de ting, der var forbudt; men ikke destomindre kunne der være dage, hvor hele Neder-Jerstal var hyllet i røg og en værre stank. Der var virkelig stank, når rugen blev brændt.

Til brændingen havde de fleste anskaffet sig en kaffebrænder, eller man lånte sig frem hos naboen. En kaffebrænder kunne man købe, det var lovligt; men det var ikke lovligt at bruge den til formålet. Når gendarmen fra Bevtoft kom ridende til byen, kunne han nemt lugte sig frem til gerningsstedet; men enten har der været noget $i$ vejen med hans lugtesans - hvad jeg nu ikke tror var tilfældet - eller også ønskede han ikke at udfolde sin magt. Der skete som regel intet fra gendarmens side.

Havde gendarmen et par soldater med på kontrolbesøg, var sagen lidt mere penibel. Vi havde som regel en halv sæk rug stående. Den måtte hurtigt gemmes væk; men det lykkedes altid, thi rygtet om deres ankomst til byen var hurtigt blevet bragt videre. Skjulestedet i vort hjem var sengen. Min søster blev altid "syg«, når kontrollen var undervejs, og i den anledning anbragt i sengen sammen med den halve sæk rug. Jeg har mistanke om, at kontrollen kendte den fidus; men der skete aldrig noget. Min mor brugte altså en lille nødløgn om det med sygdom; men jeg vil tro, hun har taget en lille snak med Vorherre i sin aftenbøn, så det ikke er kommet hende til skade.

Min mor blev under krigen "ansat « ved det kongelige preussiske postvæsen. Da der efterhånden kom militærforlægning $\mathrm{i}$ byen $\mathrm{og}$ omegn, blev der brug for et Posthilfstelle. Det blev indrettet i vor lille forstue. Inventaret bestod af en hylde, der var inddelt i små rum, og anbragt på væggen. Her blev den daglige post anbragt, der ankom med fire toget om eftermiddagen. Byens husstande kunne så her hente deres post, herunder den daglige avis. Ja, så var der selvfølgelig et ekspeditionslokale, for mors opgave var også at modtage breve og pakker og pengeforsendelser til videre besørgelse.

Ekspeditionen af disse vigtige ting foregik i far og mors sovekammer. Her var mors kommode anbragt i et hjørne, og kommodens bordflade agerede som skrivebord. Øverste skuffe i kommoden var opbevaringsted for pengekasse og frimærkekasse. Disse kassers indhold havde oprindelig været cigarer; nu gjorde de god fyldest hos det kongelige preussiske postvæsen. Uha, lad mig ikke glemme det fine runde stempel - Nieder-Jersdal - det var sandelig en vigtig bestanddel af kontorets 
rekvisitter, som i antal kunne tælles på en hånd. Kunne vi børn, når lejlighed bød sig, få fat i stemplet, blev der stemplet, både her og der; men det blev ikke tolereret af vor mor, her satte hun sin myndighed som beamter ind.

Én og anden kunne i spøg sige til mor - Marie, vi burde jo nok titulere dig som madam, for du er jo beamter. Jo, mor var »beamter«, hendes foresatte var postmesteren i Over-Jerstal. Mors kontante løn for at være beamter var lige så lille som æ posthilfstelle; men hver mark og penning var med til at forbedre hjemmets økonomi.

\section{Hverdagen i vort hjem}

Far havde mange gøremål foruden sit daglige arbejde ved banen. Tidlig forår, som regel sidst $i$ april eller $i$ begyndelsen af maj begyndte tørvegravning i Galsted mose. $Æ$ tørretøj (redskaber til tørvegravning) $æ$ flab - æ spedspade - æ skumske var god tid i forvejen gjort klar, så de var så skarpe som en barberkniv. Far havde kun søndagen og aftnerne til rådighed, så det blev nogle lange arbejdsdage, dertil en spadseretur på ca. $3 \mathrm{~km}$. fra hjemmet til mosen og omvendt. Cykler blev først fremskaffet efter krigen. Når tørvene var tilpas tørre, skulle de ringles og stakkes. Med dette arbejde skulle vi børn sammen med vor mor hjælpe til. Posthilfstellen blev lukket ved middagstid, en seddel på døren bekendtgjorde, at man kunne træffes ved 18-tiden. Forresten var åbningstiden hele døgnet, når der ses bort fra nattetimerne. Vi startede vor gang mod mosen lige efter skoletid, når vejret tillod det, det vil sige, der skulle helst være solskin. Lillebror var anbragt i den blå trækvogn. Samme sted var anbragt den nødvendige fourage sammen med et par flasker drikkelse.

Mor fastsatte et kvantum tørv, der skulle stakkes, inden vi måtte holde hvil og nyde det medbragte. Når vejret viste sig fra den pæne side, var mosen et herligt sted at opholde sig. Der var vidt udsyn hele horisonten rundt. Man kunne se helt til Rangstrupgårde, Strandelhjørn enge og et godt stykke mod vest skuede man Birkelund. Flere storkepar svævede til tider over mosen, og ikke sjældent fik vi øje på en snog, der lå og solede sig. Man kunne opleve meget sådan en eftermiddag, og ved hjemkomsten fik far en beretning fra ende til anden.

Når tørvene skulle transporteres hjem, blev der stillet hest og vogn til rådighed fra de tjenestesteder, hvor mine to brødre tjente. Det var en aftale, der var indgået, når de blev fæstet.

Når tørvene var i hus, eller i det mindste gravet, skulle der sørges for 
Forfatterens fader Anders Hansen Johnsen $i$ arbejdstojet. Foto 1915.

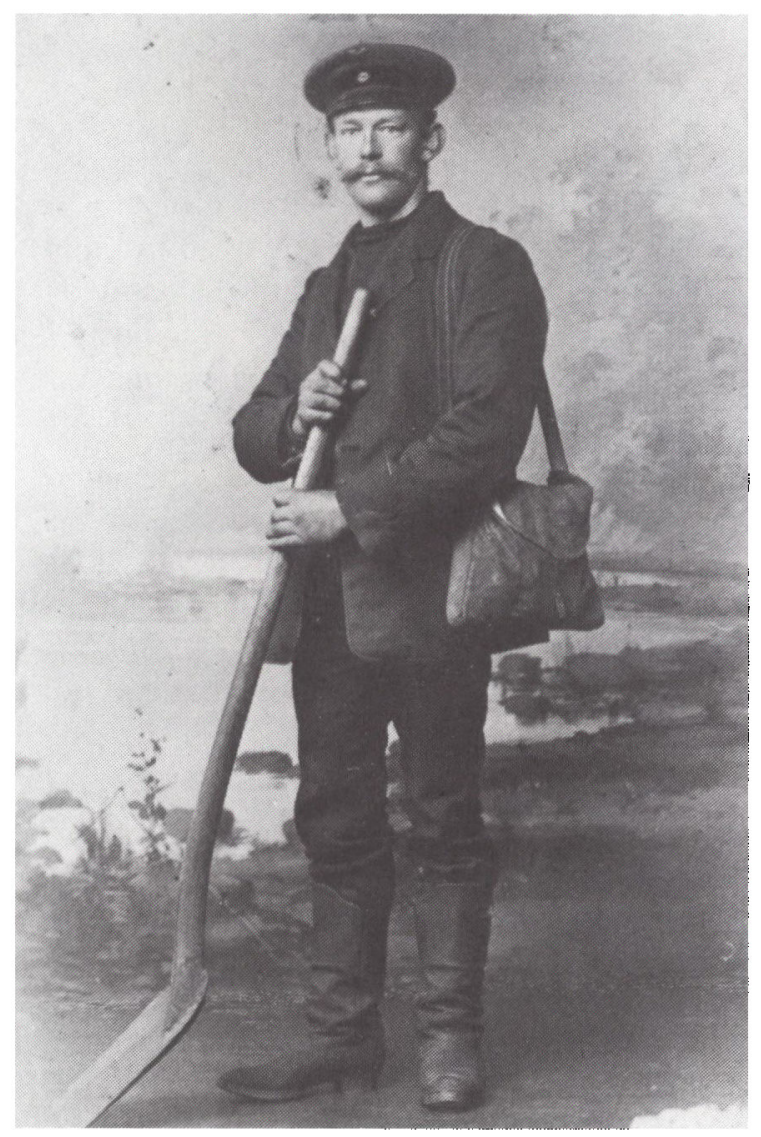

vinterfoder til gederne. Far slog græsset nede i Strandelhjørn enge, hvor der på baneskråningen var godt og saftigt græs. Efter at det var vejret, blev det kørt til Neder-Jerstal station på æa trollie. Det var en hånddreven dræsine, som normalt blev brugt på banen til fremførsel af sveller og håndværktøj. Fra stationen til hjemmet, en tre til fire minutters gang, blev høet transporteret på æ krættebar (trillebør uden sidebrætter). Høet kom op på loftet over stuehuset, hvorfra det i vinterens løb blev hentet ned til gederne.

En af de ting, der også skulle foregå i løbet af sommeren, var brændesavning. Far købte hvert forår gamle udrangerede sveller fra banen. At kunne købe disse var et privilegium, som banearbejderne havde. Disse sveller blev savet i passende stykker, så de kunne komme 
gennem kakkelovnslågen. Jeg skulle hjælpe med ved dette og havde det job at skulle holde i den ene ende af den store skovsav. Det var nu ikke et særligt interessant arbejde; men der ingen vej udenom. Der skulle som regel saves en bestemt portion hver aften i den tid, savning stod på.

Var det nu en skøn sommeraften, hvor kammeraterne legede ude på vejen eller nede ved åen, ja, så kunne ens humør godt falde til nulpunktet. En medvirkende årsag dertil var, at far havde fået den opfattelse, at træstykkerne skulle være aldeles nøjagtig lige lange, hvilket blev markeret med tommestok. Skete det ved udmåling, at dette ikke blev tilfældet, måtte de overskydende centimeter fordeles, og udmålingen begyndte forfra. Det mente jeg var spild af tid, jeg mente, at bare stykkerne kunne komme gennem kakkelovnslågen, så var det i orden. Far havde en anden opfattelse om den ting. Jeg fik at vide, at ingen kan se, hvor lang tid det har taget; men alle kan se, hvordan det ser ud, og med den tilføjelse, »og husk det min dreng«. Resultatet var også, når træet var stablet op til tørring, at man roligt kunne lade håndfladen glide ned over stablen, der var ingen ujævnheder, det hele var lavet med mm's nøjagtighed. Jeg har senere som voksen sagt til min far, at det var for pertentligt; men fik det svar som ovenfor nævnt ingen kan se o.s.v.

Et af fars gøremål var også at være hjemmets frisør. Han foretog hårklipning på os drenge. Dertil behøvedes dog ikke større færdigheder, vi blev nemlig klippet skaldet. Jeg blev 16 år, før jeg fik lov at gå til fagmanden for at blive klippet. Prisen var dengang 50 øre, fordi man var lærling, og for de samme penge fik man pomade $i$ håret, så man følte sig som en sheik efter sådan en kosmetisk omgang og inviterede pigen med ud at danse charleston.

En anden ting, som far også besørgede, var at flække sko og støvler og klampe træsko. Dertil var anskaffet en skomagerlæst. Der skulle spares på småpengene, for store var der ingen af. Jeg har senere tænkt over, at for det materielle, der daglig skulle fremskaffes, var vi børns forståelse vel ikke alt for stor. Vel, vi var dog klar over, at der skulle spares, hvor spares kunne, og lidt til, for det var en simpel nødvendighed; men personlig mindes jeg ikke at have følt det trykkende, at man ikke kunne få både dit og dat.

Vi blev først klar over, hvor fattige på jordisk gods vi havde været, da vi kom uden for hjemmets verden og oplevede andre græsgange.

Hos størstedelen i vort lille bysamfund var levevilkårene omtrent de samme. Der var forskelle; men sådan var samfundet indrettet, og den tanke, at det kunne eller burde være anderledes, var ikke nået til vor 
lille begrænsede verden. Det var den gængse opfattelse, også hos størsteparten af dem, der var på den nederste rangskala, at Gud i sin visdom havde maget det så, at der både var rige og fattige. Beviserne fandtes nok ikke $\mathrm{i}$ biblen, men blev forsvaret $\mathrm{i}$ almanakkens julefortællinger.

Nu skal man ikke tro, at mine forældre var bitre over tilværelsen. Har de følt det, gav de aldrig udtryk for det, tværtimod, de var livsglade mennesker med begge ben på jorden. Jeg tror, de var inderlig forbunden i krop og sjæl, og tog både medgang og modgang i stiv arm.

Banearbejderens arbejdsdag på banen var om sommeren 10 timer, om vinteren 9 timer. I vintermånederne, indtil det blev lyst, opholdt man sig i æ bude (skur), hvor man lavede forskellige småreparationer, det samme skete også, når der var en regnvejrsdag. Lønnen var ikke fyrstelig; men der var enkelte frynsegoder, blandt andet Krankenkasse, og dermed var hele familien sikret delvis lægehjælp, ligeledes de foromtalte sveller, der kunne købes til favørpris. Husker jeg ret, kunne banearbejderens kone også fire gange årligt køre på fribillet til Haderslev. Der var også det, at banearbejderens børn én til to gange om året var med i tildeling af tøj, som blev foretaget af Vaterländischer Frauenverein i Haderslev. Man har talt om, at denne uddeling af tøj var en del af fortyskningsarbejdet. Mine forældre har fortalt, at de aldrig direkte har mærket dette, så tøjet blev modtaget med tak. I den banekolonne, min far arbejdede, var der 5 ansatte, og de var alle dansksindede, kun banemesteren, der havde bopæl i Over-Jerstal, var tysk.

Lad mig her i forbindelse med omtale af nationalt sindelag nævne, at arbejdere og småkårsfolk og ligestillede i det store og hele ikke var direkte engageret $i$ det danske nationale arbejde, hvad nok også var forståeligt. Man var afhængig af dem, der havde magt, så man var henvist til at bruge afmagt, en naturlig reaktion og et normalt gensvar. På den måde kunne man krydse op mod vinden og undgå store og små ubehageligheder, og det var også klogest kun at udlevere sin mening i enstavelses ord.

En ekstra timeløn eller to tjente far hver sommer efter fyraften i de fjorten dage, hvor der blev kørt sand ud fra grusgraven i Neder-Jerstal. Han læssede et par jernbanevogne med hver 3 kubikmeter sand. Det gav en ekstra mark i lønningsposen. I vinterhalvåret havde far også påtaget sig et ekstra job én gang ugentlig, idet han afløste natfyrbøderen på Over-Jerstal station. Aftentoget fra Haderslev lå natten over i Over-Jerstal. Det var hans opgave at få lokomotivet køreklart til den 
følgende morgen. Kedlen på lokomotivet skulle renses, der skulle fyres op og damptryk på. Alt skulle være klart, når lokomotivfører og fyrbøder kom fra deres soverum i remisen ved sekstiden. For at få alt dette klaret måtte han starte hjemmefra ved totiden om natten, gående de fire km. til Over-Jerstal. Efter dette natarbejde startede han på sit daglige virke på banen, så det blev en lang arbejdsdag.

Endnu et ekstra job havde far påtaget sig, mere eller mindre frivilligt. Det var hver tredje søndag at gå "stræktur«, det vil sige at kontrollere banelegemet, for fars vedkommende fra Neder-Jerstal til Agerskov. Jeg har flere gange været med på denne gåtur. Om sommeren startede vi ved sekstiden og nåede Agerskov, når klokken nærmede sig 9. Hjemturen foregik med toget; men forinden kunne far nå at blive »raseret « hos barberen. Han havde altid åben søndag formiddag.

Jeg har senere tænkt på, at far og mor sjældent havde tid og lejlighed til at komme i kirke, de måtte sortere direkte under Vorherre. Det blev Guds ord ej ringere af; men klingpungen i Bevtoft kirke gik glip af en 10 pfennig.

Min mor havde også en lang arbejdsdag, fra sol stod op til sol gik ned og lidt til. Hendes ægteskabelige forpligtelse havde jo medført den store børneflok, så der var rigeligt med gøremål. Hun klarede alt indendørs, der var daglig madlavning og rengøring. Der var storvask. Det var under krigen et problem at få tøjet rent på grund af mangel på sæbe, men det blev klaret ved at koge tøjet to gange og tilsætte blånelse $\mathrm{i}$ skyllevandet. Mor foretog også kartning og spinding af uld. Uld skaffede hun sig for gode ord og betaling. Hun preklede hoes (strikkede strømper, sokker), der var syning, lapning og stopning. De to sidstnævnte operationer kunne til tider danne en hel mosaik, idet stoppekurvens indhold ikke altid kunne efterkomme de krav, der stilledes til farve, kort sagt det kunne og var til tider flerfarvet. Der var sommerens frugter og grønsager, der skulle syltes. Under krigen var det et stort problem på grund af mangel på sukker; men på en eller anden mystisk måde blev det også klaret, så der var noget at tage af i vinterens løb.

Pinserengøring var et kapitel for sig, som mor gjorde meget ud af. Gulvene fik et nyt lag lysegrå maling - tæpper på gulvene havde vi jo ikke - kakkelovnen og komfuret fik en omgang ovnsværte, stuens hængelampe fik fornyet sit guldbronce. De hvide trådgardiner blev hængt op i stuen. De var så lange, at de kunne nå nogle centimeter ud på gulvet. Det var moderne dengang, og moden skulle såvidt muligt følges. Om vinteren var der kun kulørte kapgardiner i stuen. Det var praktisk, for lampen kunne ose, kakkelovnen ligeså, og det var ejheller 
støvfrit, når askeskuffen skulle tømmes. Når dette var overstået, blev døren ind til stuen låset, og vi børn var forment adgang.

Et gebet, der i det store og hele hørte under mors område, var vi børns opdragelse. Far var jo væk hele dagen, men tog stor hensyn til mors mening om den ting. I mere vigtige og indviklede spørgsmål var det dog far, der traf afgørelsen, og jeg har på fornemmelsen, at mor syntes, det var helt $i$ orden.

Opdragelsen i vort hjem var ikke streng; men der var en kant, som ikke ustraffet kunne overskrides. Vi skulle have respekt for den afgørelse, der blev truffet, det var jo til vort eget bedste. Denne opfattelse kunne til tider betvivles fra vi børns side; men det er vel en naturlig reaktion, fordi man ikke altid kunne overse følgevirkninger. Bandeord blev ikke tålt $i$ vort hjem. Hverken far eller mor brugte kraftudtryk. Slap den slags ud af ens mund, fik man at vide, at det var tarveligt. Man fik at vide, at en »fin mand « kunne være tarvelig; men et "fint menneske« kunne aldrig finde på at tage den slags ord i sin mund. Sammenligningen var nok en hentydning til »en fin mand « i nabobyen, der brugte svovleord som perler på en snor. Jeg vil nu nok mene, at der

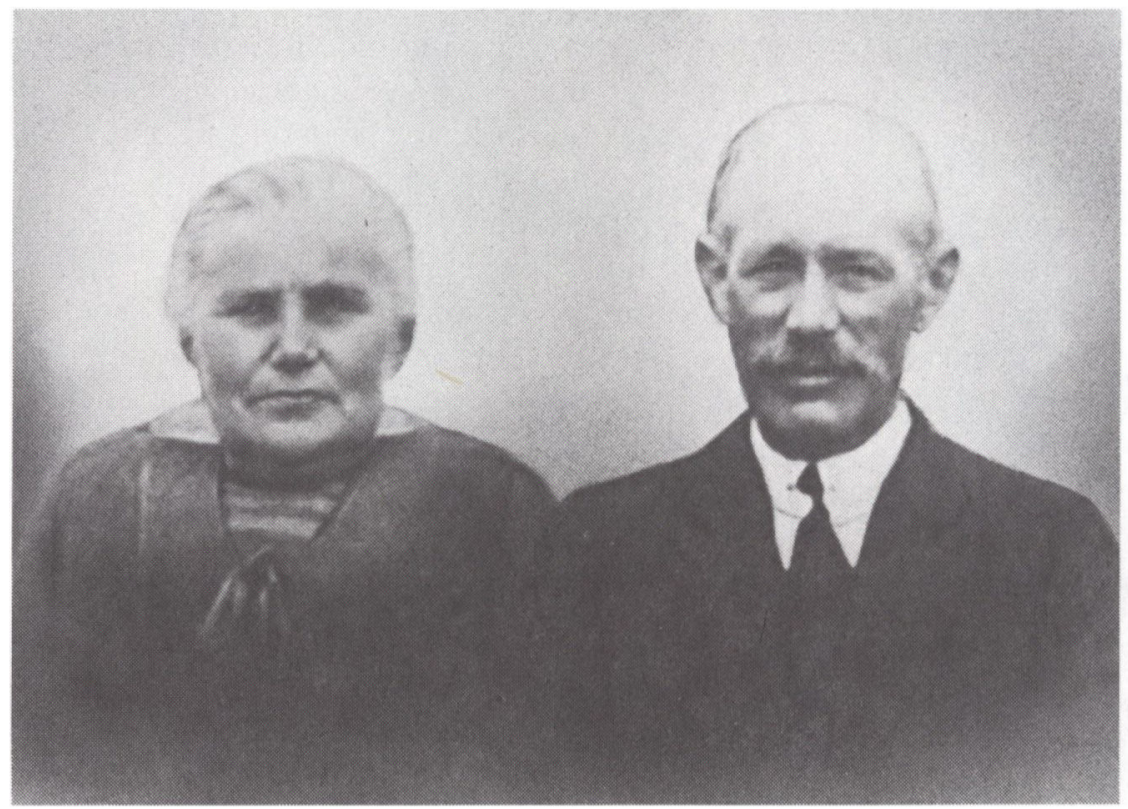

Forfatterens foraldre Marie og Anders Hansen Johnsen. Foto 1929. 
skal mere til for at være et fint menneske, men ueffen er sammenligningen ikke.

Hvad angår det seksuelle fik vi overhovedet ingen oplysninger, ikke fordi det var tabu - slet ikke. Sådan var det bare, vore forældre havde selv fundet ud af, hvordan man fik børn, så det fandt deres børn nok også opskriften på uden større forklaring. Det, at vi var omgivet af dyr til hverdag, gjorde, at man blev indviet i forplantningens mysterium og så, hvorledes det blev praktiseret.

Landsbyens piger og drenge badede også sammen nede $\mathrm{i}$ åen, og det var uden badedragt, for sådan en kendte vi ikke. Vore forældre har ikke fundet noget forkert i dette, og hvorfor skulle de også det. Var der en pige som nærmede sig konfirmationsalderen, tog hun et forklæde foran de hemmelige dele, som ikke var så hemmelige endda. Noget lignende skete ikke for vi drenges vedkommende, hvorfor ved jeg ikke.

Lad mig fortælle lidt om den daglige kost $\mathrm{i}$ vort hjem, den adskiller sig meget fra nutidens, så kan der diskuteres, hvad der var mest hensigtsmæssigt og næringsrigt. Jeg vil mene, vi fik god og nærende kost - selv i de værste krigsår; men den var meget lidt varierende fra uge til uge. Meget afhang af årstiden, og hvad haven kunne forsyne os med.

Lad mig inden jeg beskriver kostplanen fortælle, at jeg tror ikke min mor nogensinde har hørt om vitaminer. Hun havde ikke anelse om, at der var noget, der hed sådan; men per instinkt må hun have været klar over - eller måske var det erfaring fra fædrene hjem - hvad der skulle til for at holde sig i form og stimulere sundheden.

Altså, vi fik tre hovedmåltider, mellemmåltider blev ikke givet, bortset fra den rundtenom, vi havde med til skole. Efter mors udsagn var mellemmåltider usundt, maven skulle også have lov at hvile. Nå ja, følte man trang til lidt spiseligt, fandt man altid frem til et able eller en gulerod, eller i sommertiden var der rigeligt med bær $i$ haven, så vi led såmænd ingen nød.

Morgenmaden bestod af rugbrød. En tid under krigen fik vi om morgenen kun tildelt to til tre tykke skiver, påsmurt fedtegrever. Til tider kunne fedtegreverne være erstattet med en substans, der skulle illudere og gøre det ud for smør. Det bestod af kartoffelmel og gedemælk tilsat et par æggeblomme og lidt salt - kartoffelmel var lavet af egen avl. Guderne skal vide, det var et værre klister. Den eneste lighed med smør var den gule farve fra æggeblommerne. Efter hjemkomsten fra skole fik vi pilkartofler med et stænk salt, dertil et krus gedemælk.

Når far ved seks eller halvsyvtiden kom hjem fra arbejde, tidspunktet 
var afhængig af, hvor langt han var væk, fik vi unnen (middagsmad). Hovedretten var pilkartofler og duelse (sovs). Af dette kunne vi få alt, hvad vi kunne spise, derimod var kødvarer stærkt rationeret. Der kunne være et stykke flæsk, flæsketerninger eller en frikadelle. Far fik dog altid dobbelt ration. Eftermaden kunne bestå af tarregrød (boghvede), der kunne være kærnemælksuppe, saftsuppe, eller mor fandt på i sommertiden at servere surmælk. Hvad sidstnæunte angår, var jeg af den opfattelse, at der skulle et godt helbred til for at konsumere dette, især fordi sukker kun blev strøet på, som man strør salt på et stykke fedtemad. Et par af vinterens stående ugentlige retter var stuvet kålrabi og grønkålsuppe, til afveksling sort suppe (blodsuppe) fra den gris, der var slagtet sidst i november. Blodet blev hensat i store brune krukker tilsat lidt salicylsyre som konserveringsmiddel; men sidst på vinteren kunne der være dannet et lag mug oven på blodsuppen. Det blev bare skummet væk, blodet fik et opkog, intet gik til spilde. Jeg må her indskyde, at fordi vi selv fedede en gris op, var det under krigen begrænset, hvad vi kunne få af kødkort. Det skete heller ikke sjældent, at vi fik en æggekage. Vi havde selv en del høns. Æggekagen var spædet godt op med rugmel, det drøjede, den var så stiv, at den næsten kunne stå på højkant. Sådan var kostplanen i det store og hele under krigen.

En ting, som nutiden ikke rigtig kan forstå og sikkert vil undre sig over, var, at borddækning for hver enkelt kun var en dyb tallerken og en gaffel og ske - det sparede på opvasken. Derimod har vi aldrig i vort hjem langet til et fælles grødfad, som i min barndom blev brugt adskillige steder.

Efter at krigen var slut, eller rettere efter genforeningen, blev kostplanen lidt mere varierende. Far fik lidt mere i løn, der kunne "ruttes« lidt. Mor klarede det hele udmærket, også hvad angår det kulinariske, for nu at bruge et fint ord, og jeg kan sige, i modsætning til mange andre, at $i$ vort hjem er vi aldrig gået sultne $i$ seng.

Der var to dage om året, hvor vi, når vi sammenlignede med dagligdagen, levede $\mathrm{i}$ vild luksus. Det var juelaften, hvor vi fik ribbensteg, og nytårsaften, hvor der blev serveret grønlangkål og stribet flæsk. Disse to aftener fik vi også skrællede kartofler, det hørte ikke hverdagen til, for der gik for meget til spilde ved de skrællede. Juleaften og nytårsaften var også de to eneste aftener om året, hvor der blev budt på aftenkaffe, bortset fra når vi havde besøg. Ligeledes var der også det særlige ved disse to aftener, at der blev bedt bordbøn. Denne skik havde min far taget med fra det hjem, hvor han var opdraget, hvorimod der $\mathrm{i}$ min mors hjem havde været daglig bordbøn. 
Juleaften var jo noget ganske særligt. Forventningen hos os børn var stor, som den jo også er hos børn idag. Når vi havde spist, blev juletræet tændt. Det havde sin plads i et hjørne af soveværelset, i mangel af plads i stuen. Vi sang nogle julesalmer akkompagneret af far på violin. Vi fik hver én eller to små gaver, derefter aftenkaffe, og aftenen sluttede lidt over normal sengetid. Julemorgen var vi forholdsvis tidlig oppe, dels for at fortsætte legen med julegaverne, men også fordi julemorgen måtte vi spise os mætte i hjembagt kagh (franskbrød) med sirup på. Det var et incitament, der fremskyndede vor udstigning af fjerene.

Nytårsaften var i det store og hele en gentagelse fra juleaften, bortset fra gaver og det, at vi fik grønlangkål. Sengetiden var også denne aften lidt forskudt; men hele familien var til ro et godt stykke tid, før det nye år indfandt sig. Nytårsmorgen skulle der skydes nytår ind, og det gik ikke stille af. Børnene fra hele byen samledes, piger og drenge hver for sig, og så gik det løs. Nogle havde en propbøsse, andre havde i mangel af ammunition et par træstykker, der var forbundet med et stykke sejlgarn. Når disse to træstykker blev slået mod hinanden, illuderede det udmærket et lille kanonskud.

Hele byen blev afklappet, ingen gik ram forbi, på det område var vi meget energiske. De forskellige steder var man forberedt på denne invasion, så når vi nåede til vejs ende op af formiddagen, var en medbragt pose som regel fyldt med småkager og æbler. Man kunne også være heldig, men det var nu en undtagelse, at få et stykke chokolade, der var indpakket i guld eller sølvpapir. Dette papir havde lige så stor værdi som indholdet. Papiret blev omhyggeligt glattet ud og kunne blandt andet bruges som bogmærke.

Dagligdagen begyndte igen efter helligtrekongersaften, hvor juletræet blev tændt, og lysene brændt helt ned. Dagen efter begyndte skolegangen.

De fleste af landsbyens børn, der var i skolealderen, havde alle daglige pligter i hjemmet. Det havde jeg naturligvis også.

Jeg kom aldrig ud at tjene i fast plads, og de gøremål, jeg havde hjemme, var til at overse. Mit daglige arbejde var at passe gederne. De skulle om sommeren tøjres i grøftekanten langs landevejen. Det skete før skoletid. Ved middagstid skulle de vandes, og hen mod aften skulle de hentes hjem. Mor besørgede malkningen. Skete det, at mor var forhindret af en eller anden grund, kunne man spare sig forsøget med at malke. Der kom ikke en dråbe mælk i spanden. De var simpelthen obsternasige, og hverken gode ord eller trussel om repressalier havde 
nogen indvirkning. Om vinteren skulle der hentes hø ned fra stueloftet, der skulle muges ud, og en gang om året skulle de til »buks« ude hos Peter Ahlers gedebuk. Peter Ahlers boede i udkanten af Bevtoft plantage. Hans gedebuk havde ord for at være særlig god. Om den havde stamtavle, ved jeg nu ikke; men kærlighedsaffæren fik altid følger. Turen varede næsten hele dagen. Der var ca. $5 \mathrm{~km}$. hver vej, så på hjemvejen blev geden træt og lagde sig ned for at få et hvil. Jeg havde altid en madpakke med; men den var altid fortæret på henvejen, så det var både en sulten og træt dreng og ged, der nåede hjem.

En anden af mine pligter var også at holde haven i orden. Det blev den nogenlunde; men jeg er sikker på, at det ikke kunne give præmie for velplejet have. Jeg skulle også sørge for, at tørvekassen, der var placeret i køkkenet, havde forsyning, plus andre daglige småpligter; men der blev også tid til leg efter skolegang og lektielæsning.

En af sommerens beskæftigelser var at lege ved ån. Her kunne man sammen med kammerater tilbringe mange timer. Landevejen var også en herlig tumleplads. Dengang var der ikke megen trafik og da slet ikke af biler. Under krigen kom der enkelte militærlastbiler. De havde dog ikke stor fart på og kunne høres på lang afstand, så de var ingen trusel mod liv og lemmer.

Fodbold kendte vi ikke i vort gebet, for øvrigt heller ikke andre sportsgrene; men der var mange andre spændende måder at lege på. Her må jeg nok gøre en bekendelse. Der var absolut ingen ligeberettigelse mellem kønnene. Piger, de var tøse, de blev kun i yderste nødsfald taget til nåde og inddraget $\mathrm{i}$ drengenes leg, og kun når der var mangel på hankøn.

En af vi drenges spændende lege var at spille pind, den blev dyrket hele sommeren, især om aftenen. To teglsten blev stillet på den smalle langside med en afstand på ca. $25 \mathrm{~cm}$. Derover blev lagt en pind på ca. $35 \mathrm{~cm}$. længde. Med en længere og tykkere pind skulle den korte kastes så langt væk som muligt. Den lange pind blev derefter lagt oven på stenene, og med den udkastede pind skulle modspilleren forsøge at slå den lange pind af stenene. Lykkedes dette, byttede man plads, hvis ikke, målte man afstanden fra nedslagstedet og ind til stenene med den korte pind. Den, der forst fik 25 afstande, havde vundet spillet. Dette spil tror jeg er helt ukendt af nutidens børn.

Et par andre af sommerens lege var også meget populære. Det var konkurrence $\mathrm{i}$ tøndebåndsløb og ringridning. Til førstnæunte var et kasseret cyklehjul det helt store; men i mangel af et sådant klarede vi os med et stykke snoet ståltråd. Ringridningen foregik med en tyk kæp 
som hest, illusionen var tilfredsstillende, og kæppen klarede det udmærket som hest.

Vinterens lege var mere afdæmpet. De foregik ofte i lo og lade og på høloftet hos kammeraterne. Var der sne, blev det til slædeture ude på landevejen. Bakker havde vi ikke i Neder-Jerstal. Var der is på æ slunk (en lavning i terrænet ved den gamle savsevej), blev der skøjtet. Skøjter havde vi nu ikke, vi klarede os med de jernbeslåede træsko. Disse træsko var for øvrigt ofte skyld $i$, at indersiderne af ankelknoglerne var læderet; men det skulle være slemt, før vi fik en polt (linnedklud) på. Der kom som regel aldrig betændelse i såret, vor hund fik lov at slikke såret rent. Så var der fødselsdagene, de var noget helt for sig. Om eftermiddagen efter skoletid samledes man hos den, der havde fødselsdag. Som gave medbragte man som regel 50 penning, efter genforeningen blev det til 50 øre, og man forventede, at mindst samme beløb blev returneret, når man selv fejrede årsdag.

Der blev serveret kager og saftevand. Var der en kammerat, der havde fødselsdag først i det nye år, skete det jævnligt, at en eller anden højlydt gav til kende ved festbordet, at her var en kage, som hans mor havde bagt. Den var opsparet fra nytårsskyderiet, det kunne også gøres nødig, for det var ikke småportioner, sådan en halv snes drenge kunne fortære, når lejlighed nu bød sig.

En af de ting, der blev set hen til, var, når det store damptærskeværk kom til Peter Holms gård umiddelbart efter høst. Her var noget at se på; men det var påbudt, at det skete i tilbørlig afstand fra det store lokomobil. Der var mange folk beskæftiget ved tærskeværket; men ham, der betjente lokomobilet, var nu i vore øjne hovedpersonen. Det var ikke fri for, at man håbede på, at man selv kunne få sådan en stilling, når man blev voksen.

Når damptærskeværket havde været der, skete også det, at vi fik et par knipper frisk halm til sengene. Det var en hel svir at komme i seng første aften, efter at halmen var anbragt. Duften af frisk halm, og så det, man kom til at ligge så højt, at man næsten kunne nå loftet. Den gamle sengehalm var efterhånden trykket godt ned og næsten blevet til hakkelse. $\mathrm{Nu}$, jeg snakker om sengehalm, kan jeg da også fortælle, at vi havde strengt pålæg om ikke at tage noget spiseligt med i sengen. Vi måtte ikke friste musene; men det skete dog af og til, at vi fik besøg af en musemor. Der var jo lunt og godt $i$ halmen og gode redemuligheder. Blev det opdaget, at vi havde fået den slags sovefæller, gik den vilde jagt. Henrettelsen foregik i en spand vand.

Der skete immervæk noget. Fra tidlig forår til sent efterår kom 
Knivsbjerg Peter en gang ugentligt på cykel fra Over-Jerstal, hvor han boede, for at tilse de ungkreaturer, han havde gående på en mark syd for grusgraven. Jeg skylder nok en forklaring, hvad hans navn angår. Knivsbjerg var et navn, han havde fået tillagt, fordi han engang havde deltaget $\mathrm{i}$ en tysk fest på Knivsbjerg. Hans deltagelse $\mathrm{i}$ festen var vistnok sket ved en fejltagelse; men det lod ikke til, at det var en formildende omstændighed, så navnet Knivsbjerg beholdt han til sine dages ende.

Sammen med en kammerat havde jeg et særligt forhold til Knivsbjerg Peter, og lad mig her sige, at han var en flink og børnevenlig mand, så vi to knægte satte stor pris på ham, og det uden hensyn til de kontanter, der ugentligt faldt i vor turban, når han kom for at se til sine ungkreaturer. Når vi fik særlig tilknytning og fortroligt forhold til ham, skyldes det, at vi havde fået betroet at pumpe vand op til ungkreaturerne i de varme sommermåneder, og der vankede altid 10 eller 20 penning til hver, når han på sin ugentlige tur kom til Neder-Jerstal. Vi kendte nøje tid og klokkeslet, når han arriverede på sin fine cykel, der havde forkromede hjulfælge. Det var et vidunder af en cykel, og det var sådan én, man drømte om, at man engang skulle komme i besiddelse af. Den tids cykel havde på baghjulets aksel eller krank, eller hvad det nu hedder, placeret på venstre side en fodsbred stålpind, lad mig kalde den en hønsepind, anden betegnelse for denne har jeg ikke kendt. Denne pind havde sin særlige funktion, når man skulle starte. Man stillede sig bag cyklen med den venstre fod på hønsepinden og løb tre til fire hop på den højre fod, så var farten tilstrækkelig til, at man kunne svinge sig op i sadlen.

Jeg må ikke glemme den årlige sensommertur til Hjartbro skov. Vi startede over middag vel omkring 12 til 15 drenge og piger. Turens formål var at plukke blåbær - plukke og plukke - nå ja, det blev mest overladt til pigerne. Hvad vi drenge plukkede, forsvandt straks i munden, for vi skulle nu, når lejlighed bød sig, lege røvere og soldater $\mathrm{i}$ en rigtig skov. En anden vigtig ting, vi skulle have opklaret, var, hvor æ Ullentorre (Oldenborre) holdt til. Man sagde, at der var en koloni af dem i Hjartbro skov. Vi fandt den nu aldrig. I min drengetid mener jeg at kunne huske, at vi havde to oldenborreår. De kom flyvende helt til Neder-Jerstal, og om aftenen, når de havde sat sig til ro i træerne, rystede vi dem ned, puttede dem $i$ en spand, de blev skoldet, og så var de et udmærket hønsefoder. Udbyttet af turen, hvad angår blåbær, var en del tilbage at ønske, og pigerne var uforskammede nok til at fortælle, at det var vi drenges skyld. 
Klapjagten om efteråret i Bevtoft plantage var også en årlig tilbagevendende begivenhed, som man glædede sig til. Da vi havde en kammerat i skolen, hvis farfar var skovfoged i plantagen, så var det en selvfølge, at drengene fra Neder-Jerstal skole skulle være klappere. Det gav en fridag fra skolen, og tænk, man fik dagløn. Jeg kan huske, at ved den første klapjagt efter genforeningen fik vi 2 kroner i dagløn, det var for os en hel formue.

Togets ankomst om eftermiddagen fra Haderslev var noget, man nødig gik glip af, medmindre pligten kaldte til andet nødvendig gøremål. Ved dette togs ankomst skete der en hel del. Toget medbragte den daglige post af breve og pakker, især til de soldater som havde ophold $\mathrm{i}$ byen og omegn, desuden den daglige avis Modersmålet.

Posten blev ved toget afhentet af min mor eller min aldre broder. En meget vigtig person var også med dette tog, det var bybud Paulsen fra Toftlund. Han tog med morgentoget til Haderslev to gange ugentligt og modtog ved hver station bestilling på tjenesteydelser. Når han returnerede med eftermiddagstoget, blev det bestilte afleveret. Det økonomiske skulle ordnes, måske også en nærmere forklaring om det købte. Det var krigstider, så det var ikke altid, man kunne få det ønskede, hvad

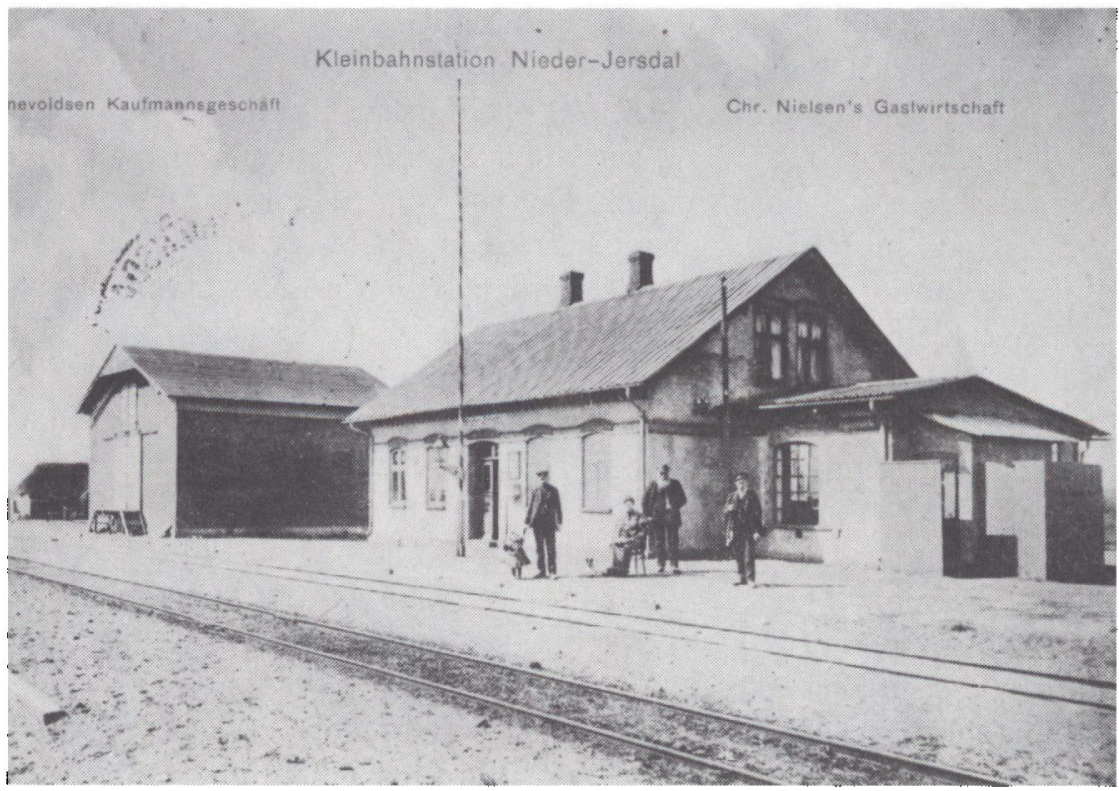

Neder-Jerstal station. Postkort fra omkring 1910. 
størrelse, farve, kvalitet angår. Paulsen hævdede altid at have gjort sit bedste. Det hele tog lidt tid; men der blev ikke fløjtet afgang af schaffneren, før Paulsen tilkendegav, at alt var ordnet.

Paulsens ordreliste kunne til tider også være lang. Der kunne være bestilling til apotek, nogle skulle have det fra det tyske Løveapotek, andre fra det danske Hjorte apotek, alt efter national indstilling; men Paulsen opfyldte alle ønsker, så kunderne kunne være tilfredse. Der kunne være bestilling på sålelæder til klodser og træsko. Det fik man bedst hos læderhandler Thamsen i Storegade, galanterivarer og billedrammer i Sabroes boghandel. Man kunne sende tante Annes foto med Paulsen om morgenen; hun blev afleveret om eftermiddagen i en pæn sort oval ramme med guld staffering. Der kunne være bestilling på en kasket med eller uden blank skygge, det kunne være en »klipfisk « - den med en lille sort sløjfe - eller en celluloidflip, den var pæn til sort tøj, og den kunne tørres ren med en fugtig karklud. Størrelsen fik Paulsen opgivet $\mathrm{i}$ form af en papirstrimmel, så alt kom til at passe som fod $\mathrm{i}$ hose. Mange andre småting, man behøvede, skaffede Paulsen fra Hundevadt. Man kunne også medgive Paulsen en fuldmagt, når der var noget, der skulle ordnes hos offentlige myndigheder f.eks. på Katasteramt. Der var ikke den ting, Paulsen ikke kunne imødekomme, så hans store bærekurv, som han bar på ryggen $\mathrm{i}$ et par læderremme, var toppet, når han entrede toget på Sønderbro.

En anden fast kunde, der daglig benyttede toget, var lille Madsen med æ trækasten. Han havde bopæl i Haderslev, han havde wandergewerbeschein (vandrebrev) og berejste hele amtet. Fra sin kasten kunne han faldbyde forskellige småting. Der var knapper i forskellige størrelser, sytråd, snørebånd, smergellærred, lommeknive og meget mere. Priserne var nok i overkanten af værdien; men Madsen var velkommen i mange hjem. Han medbragte jo altid de sidste nyheder fra æ staj. Havde man familie eller venner og bekendte $\mathrm{i}$ hans rejseområde, kunne man medsende hilsen og kunne modtage genhilsen. Den slags ærinder styrkede forretningens omsætning, og om ikke andet så var han sikker på kaffe eller et måltid mad. Hans første handling efter ankomsten til Neder-Jerstal med morgentoget var at indfinde sig i vort hjem for at få morgenkaffe. Derefter en rundgang i byen, så var det lige afpasset, at han kunne nå ud til Lykkeskovs, der boede ved Bevtoft plantage, og så var middagsmaden sikret.

En anden type af godtfolk, der også var stamkunder ved a lillebahn, var egnens grisehandlere, der var fire, altså lige det antal, der skulle til, for at man kunne få et slav kort. En gang ugentlig var de med 
morgentoget mod Haderslev for at udøve deres erhverv på æ grismærken. Navnene på dem husker jeg ikke, bortset fra Johs. Hermansen (som nogle år senere blev vor gode genbo i Over-Jerstal); men jeg husker, at de alle fire var sværvægtere, og rangerede i 200 punds klassen. Jeg vil tro, det hørte med til professionen. I en kreaturvogn var grisene anbragt i solide grisekasser, mærket med ejerens navn og adresse. Ejerne, altså grisehandlerne kørte på 2. klasse. Her var et rundt bord og plysstole, så man kunne sidde behageligt, og man kunne udnytte tiden med at spille kort. Man returnerede som regel med eftermiddagstoget, bortset fra at det kunne ske, at lidkøbet i Nissens gæstgivergård på Gravene trak lidt ud; men så havde man et senere aftentog at falde tilbage på.

Et par gange om året - måske flere, det husker jeg ikke bestemt skete der det, at eftermiddagstoget havde en celeber person med. Den fornemme og aristokratiske person - sådan blev han betragtet af almindelige dødelige - var »æ Direktor « for banen. Hans salonvogn var koblet til som bageste vogn i toget. Rygtet om hans færd var gået forud, så fanen var hejst på stationen. Toget overholdt nøje køreplanen på minut, den dag gjaldt »Ordnung muss sein «, det kunne det ofte knibe med til daglig. At skue denne fine salonvogn og måske få et glimt af hans excellence, det var noget, man ikke måtte gå glip af. Jo, der skete immervæk noget på stationen, det var Neder-Jerstals navle.

Så var der søndagen. Den havde sin særlige atmosfære, det hele var mere stille og afslappet. Vi var en lille flok fra Neder-Jerstal, der gik til søndagsskole hos gårdmand Jens Riss $\mathrm{i}$ Jægerlund. Det var fru Riss, der ledede søndagsskolen. Hun havde evne til ved sin levende fortællemåde at få os til at lytte, og fællessangen var for os børn en oplevelse, som var ny hver søndag. Det, søndagsskolen gav sammen med bibelhistorien i skolen og vore forældres livssyn, var det, der grundlagde vor kristentro, der senere i livet skulle blive det bærende i medgang og modgang. Hvert år blev der holdt sommerfest for søndagsskolen i haven hos familien Riss og juletræsfest mellem jul og nytår. De of rede både tid og penge på deres kristentro. Lad mig $\mathrm{i}$ forbindelse med ovennævnte fortælle, at under krigen tog de en svagelig dreng i pleje. Han var fra et arbejderhjem, hvor moderen var død. De praktiserede næstkærlighed, var altid rede med hjælp til deres medmennesker, såvidt deres økonomiske formåen strakte. For dem var det en ganske naturlig pligt som kristne mennesker, og lad det være sagt, deres gerning og væremåde skabte respekt om dem $\mathrm{i}$ vort lille bysamfund.

Lad mig slutte dette kapitel med en omtale af en betydningsfuld 
epoke i mit liv. En epoke som enhver dreng må gennemgå og som sikkert har eksisteret helt fra skabelsens dage. Jeg tænker på, da man nåede pubertetsalderen, hvor indre kræfter og følelser kom til bevidsthed, og hvor drenge $i$ den alder lader fantasien boltre sig frit. Man fik anbefalet, at læse pastor Olfert Ricard's ungdomsbøger. Inden jeg går videre må jeg fortælle, at pastor Olfert Richard var en mand med umådelig indflydelse. Han havde været generalsekretær for K.F.U.M. i Danmark, inden han blev sognepræst ved Garnisonskirken i København. Han repræsenterede en idealistisk, etisk vækkende forkyndelse. Han var en god ungdomstaler og prædikant, men jeg kunne dog allerede i min ungdomstid se, at hans syn på det kønslige, også ud fra et kristent standpunkt efter min mening hvilede på et forkert grundlag. Mange unge mennesker kom til at lide af religiøse anfægtelser, når de ikke kunne overholde Olfert Richard's troslære om det seksuelle liv.

\section{Når doktoren og døden kom til byen}

Nu skal overskriften ikke forstås på den måde, at doktoren havde døden med $\mathrm{i}$ sin lægetaske, når han mødte op. Lad forklaringen være den, at var der sendt bud efter doktoren, regnede man med, at patienten var i dødens forgård. Der var kun det håb, at doktoren kunne lave et mirakel og lidt til. At sende bud efter læge for lidt ondt hist og her, blev aldrig gjort. De almindelige børnesygdomme blev klaret med gode hjemmeraej (råd). Jeg mindes ikke, at vi i de ti år, vi boede i NederJerstal, havde haft bud efter læge eller har været $i$ hans konsultationsværelse. Når der endelig var nogen, der skulle have læge, blev der sendt bud efter dr. Johansen $\mathrm{i}$ Toftlund. Han var en gammel erfaren læge, og det skal også siges, at han kunne give gode råd og anvisninger både for dit og dat. Han kunne sige de rigtige ord på det rigtige tidspunkt, så alle forlte sig trygge, og resten lagde man i Guds hånd, så var man helgarderet, hvad der end skete.

Folk døde dengang, såvel som nu; men måden, man tog dødens ankomst på har helt forandret sig. I min barndom blev døden omtalt som den naturligste ting på denne jord, hvad den jo også er. Døden var ikke et tabu emne imodsætning til idag.

Med meget få undtagelser skete alle dødsfald i hjemmet, den døende var $i$ vante omgivelser, omgivet af sine kære, og var man nået op til støvets år, så vidste man, at døden kom og hentede en til den store lange rejse.

Den afdøde stod som regel i hjemmet fra 5 til 6 dage, før begravelsen 
fandt sted. Landsbyens børn mødte næsten alle op for at se den afdøde, når han eller hun var lagt $i$ kiste. Dengang var en kiste altid malet sort. For lidt mere velhavende kunne det dog være en egekiste, og ualmindeligt var det ikke, at den afdøde selv havde lagt penge til side til denne. Når vi mødte op for at se den døde, medbragte vi en krans, som var bundet af grønt og det, man efter årstiden havde af blomster $\mathrm{i}$ haven. At købe en krans var næsten utænkeligt.

I forbindelse med et dødsfald, var der meget at tage vare på. Følget skulle have kaffe i hjemmet før jordefærden. Familien og nærmeste naboer og de, der var budt til at bære, skulle efter begravelsen have suppe. Derfor var dagene forud præget af travlhed med at bage og koge. Man ønskede som regel at give den afdøde en pæn og stilfuld begravelse, så vidt den økonomiske formåen rakte. Det at indbyde pr. bud til begravelsen blev efterhånden afskaffet. Det blev mere almindelig under krigen, at man i en dødsannonce i Modersmålet bekendtgjorde for slægt og venner, at begravelsen foregik om Gud vil på ---dag kl. 2 fra hjemmet, og der bydes kun af denne vej. Med denne bekendtgørelse var det underforstået, at der for følget var kaffebord i hjemmet før begravelsen.

Et par dage efter dødsfaldet indfandt ligsynsmanden sig $\mathrm{i}$ den afdødes hjem. Det var et borgerlig ombud at være ligsynsmand. Hans opgave var at fastslå, at døden var indtrådt. Det foregik på den måde, at han stak hovedet ind af døren til den stue, hvor den afdøde lå, hvorefter Chresten, sådan hed ligsynsmanden, udtalte - fred være med dig - og som regel tilføjedes den afdødes fornavn. Når denne ceremoni var overstået, det tog vel 10 sekunder, og det uden at Chresten gav slip på sin halvlange pibe, blev der serveret kaffe og kager for Chresten. Piben blev stoppet, og så fik han en lille holdsnak, hvorefter han i embedets medfør udstedte dødsattesten på en dertil autoriseret formular underskrevet med Chrestens navn.

Bogstaverne hældte hver sin vej; men han havde gjort sit bedste $\mathrm{i}$ skrivekunsten, og præsten kendte Chrestens krusseduller. Hvis Chresten ikke $\mathrm{i}$ egen person kunne møde op til begravelsen - hvad dog sjældent var tilfældet - og selv overgive præsten dødsattesten, blev den efterladt $i$ den afdødes hjem med en stærk påmindelse om, at man endelig ikke måtte glemme at medtage den til præsten. Med Chrestens signatur var loven sket fyldest, den afdøde kunne nu, med Chrestens sagkundskab og velsignelse roligt sænkes i graven.

Begravelsesdagen var også en begivenhed for os børn. Det var børns gøremål at strø grønt på vejen, hvor ligvognen og følget skulle passere 
gennem byen. Såvidt gørligt var alle de voksne fra byen med i følget, så det kunne til tider være et langt vogntog, der fulgte efter ligvognen. Ligvognen blev kørt af en mand i sognet, der havde påtaget sig denne opgave og var $\mathrm{i}$ besiddelse af et par passende heste. Hestene var dækket af et sort skaberak og ligvognen draperet med sort nedhængende klæde med sølvfrynser.

Mændene mødte til begravelsen i diplomatfrakke og høj hat. Da det ikke var hverdagstøj, men havde varet gemt hen i skab og skuffe, duftede det af en blanding af lavendel og naftalin. Kvinderne mødte også $\mathrm{i}$ sort, både $\mathrm{i}$ kjole og overstykke. De nærmeste kvindelige familiemedlemmer til den afdøde, havde sort slør fastgjort på hatten, således at det faldt ned foran ansigtet. Det hørte sig til, når man ville være korrekt påklædt og følge moden. Var det manden, der var den afdøde, bar enken skulderlangt sort slør. Dette blev båret i hele sørgeåret, når hun viste sig offentligt. Var det manden, der havde mistet sin ægtemage, bar han i sørgeåret sort hattebånd og sort armbind. Jo, der var stil over det hele, når man mødte op for at ære den afdøde.

\section{Naboskab og lidt af hvert}

Som jeg før har omtalt, var der kun få gange, min far og mor havde lejlighed til at komme i kirke; men min mor var dog altid i kirke ved én af de to årlige altergangsgudstjenester. De af menigheden, der ville til alters, skulle indskrives hos præsten nogle dage $\mathrm{i}$ forvejen, og jeg erindrer, at jeg har været sendt afsted til pastor Schmidt med besked om, at min mor ønskede at deltage i altergangen.

Jeg har senere tænkt på, hvorfor der kun var altergang to gange årlig. Måske var det bare, fordi sådan havde det altid været, så det var der ingen grund til at lave om på. Der var måske også det, at folk i Bevtoft sogn ikke syndede så meget, og så var der jo ingen grund til at ulejlige Vorherre unødig, eller hvad der er mest sandsynlig, man havde bibeholdt en del af den gamle bestemmelse fra den tid, da hver voksen mand eller kvinde $\mathrm{i}$ sognet var tvunget til at kommuniere mindst en gang årlig. For at man dengang kunne holde styr på dette regnskab, var indskrivning til altergang nødvendig. Denne indskrivning var altså stadig gældende for sognets sjæle, når man ville besøge Herrens bord; men tvangen med at gå til alters var dog afskaffet.

Jeg har en enkelt gang været med min mor, når hun var til altergangsgudstjeneste. Mor havde til denne lejlighed sin sorte kjole og overstykke på, det hørte sig til, når man ville gå til alters. Pastor 
Schmidt var på prædikestolen i en stiv klokketime. Hans tilhørere skulle have noget for pengene, når de endelig havde bevæget sig hen $i$ kirken. »Betalingen « kunne erlægges i klingpungen, der af degnen blev båret rundt under sidste salme før prædikenen. Den sidste salme før prædikenen havde altid mange vers, så degnen kunne nå alle stolestader igennem, før salmesangen sluttede. Det, der kom i klingpungen ved søndagsgudstjenester, blev brugt til velgørenhed op til jul.

Det var en lang sitzung sådan en gudstjeneste, for mit vedkommende spildt tid. Præstens prædiken trængte ikke ind i min kyllinghjerne, til gengald var jeg aktiv i salmesangen; der gjorde jeg mit bedste. Efter gudstjenesten skulle mor hilse på venner og bekendte, især når der var naboer fra vort foregående hjem i Hyrup. De sidste nyheder blev udvekslet og kommenteret, så inden vi fik travet turen fra kirken og nåede Neder-Jerstal, var der gået et godt stykke tid over middag.

Mine forældre havde faktisk ingen omgangskreds. Der var hverken råd eller tid til selskabelighed. Fars og mors familie var med den tids transportmidler for langt væk. Skulle der aflægges dem et besøg, skulle det ske på en søndag eftermiddag, mere tid var der ikke til rådighed. Ferie var et ukendt begreb bortset fra børn og skolelærere. Hele familien kom dog regelmæssigt, især om vinteren, ned til fars kollega ved banen Ludwig Bahr og hans kone Christine, og de kom også op til os. Når jeg skriver ned og op, skyldes det, at vi boede på hver sin side af ån, og at der var en svag stigning i terrænet fra åen og op til vort hjem.

Ved disse aftenbesøg var vi børn som regel med, idet Ludwig og Christine havde børn, der var nogenlunde jævnaldrende med os. Blandt dem var Sophie, som var min skolekæreste. Hun var den kønneste pige i mine drengeøjne, og jeg tror også, hun syntes, at jeg var den kønneste dreng af alle drenge i skolen.

Ved disse aftenbesøg vankede der kaffe og kager, dog $\mathrm{i}$ al beskedenhed. Vi børn legede, vore forældre spillede skærvindsel, eller det skete, at der blev holdt sangaften. Ludwig havde en særlig god sangstemme. Et af hans store numre var Edelweis, og min far leverede musikken på violin eller harmonika.

Det kunne også ske, at min far læste op af Nordslesvigs Goodtemplar Almanak eller Sprogforeningens Almanak. Begge almanakker indeholdt små afsluttede fortællinger, til tider var disse rørende til tårer, så vi børn lyttede spændt med. Disse to almanakker var faktisk den eneste lekture, der blev købt, plus den daglige avis. Det var ikke nødvendigt med en boghylde i vort hjem. Vi ejede en bibel, en salmebog og en lille bog om sundhedspleje $i$ hjemmet, plus en stabel gamle 
Familie-Journaler fra før krigen. De sidstnæunte var bogstavelig talt slidt op; dem havde vi børn gennempløjet mange gange.

Jeg har liggende foran mig, mens jeg skriver dette her, Goodtemplar almanakken fra mit fødeår 1909. Den udkom indtil verdenskrigen begyndte, og udgiver var den kendte danske mand Chr. Lageri i Haderslev. Trykkested var Haderslev og prisen var 35 penning. Nu synes 35 penning jo ikke at være meget, men som jeg før har omtalt, er det sket, at min far har tærsket en hel vinterdag for 50 penning, og senere ved banen var 35 penning en hel timeløn, så almanakken blev ikke bare smidt væk, den blev læst gang på gang, indtil en ny kom ved juletid. Almanakken havde omkring 64 sider læsestof og samme antal sider med annoncer, plus det normale kalenderstof, herunder alle markedsdage $\mathrm{i}$ hele Danmark og Nordtyskland. Ja, så indeholdt den også en anden vigtig ting. Den fortalte læserne, at året 1909 indtraf 5876 år efter verdens skabelse, og kan man sin tabel, kan man jo hurtig regne sig frem til nuværende årstal for skabelsen.

Gensidige tjenesteydelser for naboer og venner var meget udbredt, også mellem min mor og Christine. Folk fik dengang som nu børn, dog flere og i hurtig rækkefølge. Ludwig og Christine var ingen undtagelse, hvad det angår, og mor ydede hjælp og bistand så meget hendes tid tillod. Christine fødte i 1921 en pige, som i dåben fik navnet Petra. Dette var jo nu ikke særlig bemærkelsesværdigt, men når jeg omtaler dette, har det sin særlige årsag.

For at værne Petra mod rakitis (engelsk syge) skulle hun ved solnedgang nøgen gennem en sait (græstørv). Denne hellige handling foregik en skøn stille sommeraften. Ceremonien foregik på den måde, at Ludwig nede $\mathrm{i}$ engen ved åen stak et par saiter og stillede dem på højkant, ligeledes en sait som overligger. I det øjeblik solen forsvandt under horisonten blev Petra løftet gennem åbningen. Christine på den ene side og min mor til at tage imod på den anden side. Der måtte under handlingen, for at den kunne virke, ikke mæles et ord.

Vi børn stod ved den store bro og var stille tilskuere. Min mor var nu ikke videre rettroende på det område; men hun ville da gerne gøre Ludwig og Christine denne vennetjeneste. Det kunne da heller ikke skade, hverken den ene eller den anden, og hekseforfølgelse var jo afskaffet. Petra fik ikke rakitis og lever endnu i bedste velgående. Dette at børn skulle igennem en sait for at værnes mod rakitis, var ikke ualmindeligt på egnen, selv folk, som man skulle tro vidste bedre, foretog denne handling.

Et andet godt hjemmeråd som blev benyttet ved lændesmerte 
(hekseskud) var at blive pisket over lænden med et knippe brændenælder. Denne behandling var slet ikke dårlig, musklerne blev varmet op, men når operationen var overstået, var patienten det pågældende sted rød som en kogt krebs - med ondt skal ondt fordrives - metoden var billig, man sparede doktoren og snød apotekeren.

En af dem, der daglig aflagde vort hjem et besøg, var gamle Thie Midtgaard. Hun boede $i$ et lille stråtækt hus, hvor vejen skiltes efter Bevtoft og Galsted. Thies indtægter strakte nok kun til det allernødvendigste. Foruden rengøring af skolen havde hun salg af kovringer (tvebakker) og lidt andet fra bageren i Bevtoft. Blandt disse andet var en småkage, ovenpå belagt med korender. Vi kaldte den Rasmusses kage. Navnet havde vi givet den efter vor nabo Rasmus Jepsen. Det skete af og til, at Rasmus sendte os ned efter en tut korendekager, to for 5 penning, og vi var altid sikker på, at der var en 5 penning ekstra til egen forsyning. Til fastelavn kunne Thie også forsyne byen med hedeviger (fastelavnsboller). Mit hjem var dog ikke aftager. Mor bagte selv, hun var af den formening at de kjøfens (købte) var for udrøje. Foruden fra skolen og bageren havde hun også lidt indtægter ved at vaske og lappe tøj for byens og omegnens karle, dertil kom også lidt indtægter ved, at hun havde taget et par piger i pleje. Disse pigers moder var bleven bedreget (bedraget, forført) eller som det også hed dengang, kommen galt afsted. Disse piger fik en god og kærlig opdragelse hos Thie, hvad de også senere som voksne gav udtryk for.

Thie var en reservedoktor, man henvendte sig til, når der var mindre skavanker, der krævede behandling. Thie kunne fjerne ringorme, vorter, årelade, fjerne knyster, klarede også en bullen finger og meget mere. Personlig er jeg bleven behandlet hos Thie for at få fjernet en ringorm. Ringormen blev fjernet på den måde, at Thie skrev nogle hemmelige tegn på et stykke papir. Papiret blev syet fast på indersiden af skjorten. Efter tre dage mødte man op hos Thie, fik papiret med skriften fjernet, papiret blev brændt og ringormen var væk, ja det er visselig sandt.

Thie var et gudfrygtigt menneske, altid hjælpsom med råd og dåd. Hun levede sine sidste år hos et af sine plejebørn.

Vor nærmeste nabo på vejen mod Over-Jerstal var skolen, og vi havde et godt naboskab til lærerparret og til deres børn som hørte med til vor legekreds. Lærer Stäcker og hans kone var de eneste i byen, der blev tituleret med De og Hr. og Frue, og det skal også siges, at det var de eneste, kasketten svang af hovedet for, når man mødte dem. Lærerparret var flinke og hjælpsomme folk. Skete det, at vi fik liggende 
gæster for en nat eller to, var de altid rede med at yde sengeplads. Fru Stäcker var ikke videre stiv i det danske sprog, og min mor til gengæld ikke i det tyske; men blandingen blev som regel forstået. Jeg skal her give en lille prøve på min mors tyske sprogkundskaber. En sommerdag var den ældste af Stäckers drenge, Oswald hed han, ovre hos os for at lege. Af en eller anden grund må han have været uønsket, for min mor gjorde ham opmærksom på, trods min protest, at han hellere måtte gå hjem, idet der var udsigt til "Donnerwetter«. Oswald gik hjem og fortalte, at madam Johnsen havde sagt, at der blev Donnerwetter. Næste dag fru Stäcker traf min mor, spurgte hun, hvad det var, dette Donnerwetter, hun havde da aldrig hørt min mor bruge bandeord, så hun kunne ikke fă Oswalds forklaring til at rime nogen steder. Mor fortalte hende, at det var da rigtig nok, der blev da tordenvejr. Et større smil bredte sig over fru Stäckers ansigt, og så fik mor en lektion i tysk og forklaret forskellen mellem Gewitter og Donnerwetter. Nej, vor mor var ikke stiv i det tyske; men efterhånden som krigen skred frem, lærte hun dog en del af de tyske soldater som daglig kom for at hente og aflevere post.

Naboskabet blev også plejet på den måde, især om vinteren, at en eller anden dryssede ind en aftenstund for at sludre lidt eller drøfte, hvad dagens avis havde berettet. Dengang kendte man jo ikke radio og fjernsyn, og telefon var ikke hvermands eje. Den eneste telefon i NederJerstal fandtes på stationen, og den var til brug for banen.

Varede et besøg ud over fars normale sengetid, havde han sin egen måde at gøre gæsten opmærksom på, at nu måtte vedkommende gerne forsvinde. Havde klokken slået 22, og det var det yderste far strakte sig til, rejste han sig fra stolen og vrej æ klok (trak stueuret op). Så vidste gæsterne, at nu måtte de gerne forsvinde. Man kunne dog finde på at drille far, idet man trak tiden lidt ud; men gik der mere end ti minutter, kunne man være sikker p̊̊, at han sagde godnat og forsvandt og overlod det videre til mor. Man kendte min fars måde at være på, og alle morede sig.

Far kunne også vise sig som handlingens mand i en given situation. En morgen, før han tog på arbejde, havde han af mor fået besked på, at medtage nogle varer fra Jepsens høkerbutik i Strandelhjørn, blandt andet sirup og ikke at glemme et styk af det unævnelige natmøbel, som havde sin plads under sengen. Men i skyndingen fik han ikke den brune sirupspotte med hjemmefra. Gode råd var dyre, men som sagt han var en handlingens mand. Jepsen fik besked på, at fylde natpotten med sirup, efter at den ny potte havde fået en tilbørlig afvaskning i fru 
Jepsens køkken. Fars konduite blev nu ikke påskønnet, da han kom hjem med sirup i natpotten. Mor hærpede siruppen i svinetønden. Her vil jeg nok mene, at min far burde have været dagens mand; men min mor havde en anden mening om den ting.

Under 1. verdenskrig havde vi, hvad jeg må kalde rigtige udflugter. Den første var i 1916 hvor vi var med toget til Victoriabad ved Kelstrup strand. Jeg husker, det var en skøn og varm højsommerdag; men ellers står der ikke meget i min erindring om den tur, dog husker jeg, at jeg så en mand, der var ude at svømme. I mine øjne var hans svømmetur omtrent helt over til Als. Det har nu nok ikke været tilfældet; men jeg er sikker på, at han var så langt ude, at han ikke kunne bunde.

I det svære krigsår 1917 havde vi også en udflugt. Den foregik til brødremenighedens missionsfest i Christiansfeld. Denne udflugt står fast i min hukommelse. Turen foregik med toget, men på grund af mangel på personvogne, var der tilkoblet lukkede godsvogne, hvori var indsat bænke. Jeg kan huske, at vi var anbragt $i$ en sådan vogn. Det var jeg nu ikke særlig tilfreds med, man kunne jo ikke nyde udsigten; men trods denne skavank blev det en god festdag med mange oplevelser. Der var medbragt smurt brød med pølse og gedeost, og for tørstens skyld var medbragt et batteri af flasker, hvis indhold var ribssaft, selvfølgelig godt fortyndet med vand fra $æ$ kehl. I Christiansfeld var vi hos fotografen, hele familien blev aftegnet på et fælles billede. Jeg

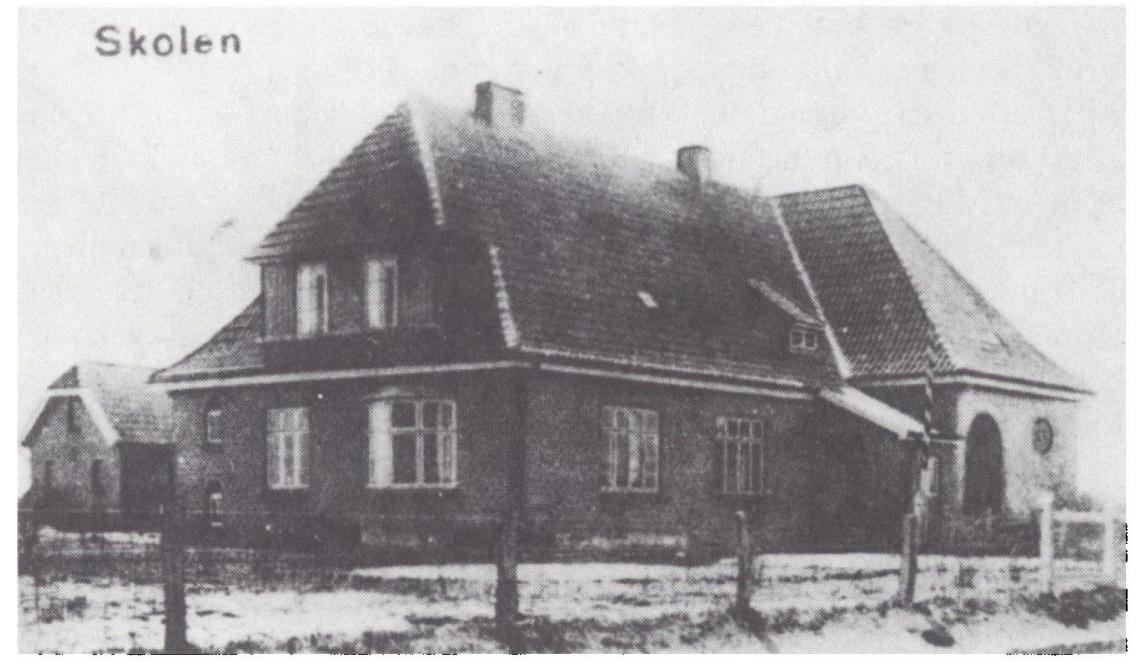

Neder-Jerstal skole 1913. 
husker tydeligt fotografens atelier, og hvorledes han stak hovedet ind under et sort klæde, som hang bagpå apparatet. Han løb frem og tilbage, skubbede med en lang stang på nogle hvide gardiner, som dækkede noget ovenlys. Endelig må han have ment, at alt nu var, som det skulle være, for pludselig mens han havde hovedet under det sorte klæde, gav det et knips, og resultatet af anstrengelsen både for ham og os blev tilsendt nogle dage senere. Det var en spændende dag, med mange oplevelser og kunne ikke sammenlignes med hvad som helst. Sådan en udflugt var jo hverken hverdags eller søndagskost, så den kunne huskes $\mathrm{i}$ årevis.

\section{Våbenstilstand og genforeningen}

Så kom våbenstilstand, kanonerne tav den 11. november 1918, 1. verdenskrig var forbi. Om budskabet har gjort et særligt indtryk på mig, erindrer jeg ikke; men jeg husker, at vagtposten ved broen pludselig var væk. Dagen efter stod han der igen, så man kunne næsten tvivle på, at krigen var forbi. På stationen i Neder-Jerstal stod et par vognladninger hvidkål. Meningen har nok været, at de skulle sendes til de hungrende storbyer; men de var altså ikke blevet afsendt. Vi var nogle knægte, der blev enige om, at nu da krigen var forbi, og ingen syntes at interessere sig for disse hvidkål, så kunne vi da fordele dem $\mathrm{i}$ vor by. Som sagt så gjort, vi fik fat i en trækvogn, kørte rundt i byen og delte hvidkål ud til højre og venstre. Dette initiativ og gavmildhed fra vor side fik en brat ende. Manden, der havde leveret hvidkålen på jernbanevognen, kom og stoppede vor gode gerning.

Bagefter har jeg kunnet se, at tiden umiddelbart efter krigens afslutning var en lovløs tid. De tyske soldater, som endnu opholdt sig i byen og skulle bevogte depotet, holdt udsalg i lange baner. De grå militære sovetæpper kom til at gøre god fyldest rundt om i hjemmene. Trillebører, kikkerter, tømmer til hele huse og meget mere skiftede ejer. Kontanter eller fødevarer blev af de tyske soldater modtaget som betaling. "Ordnung muss sein« var sat ud af kraft, eller det blev fortolket på sin egen måde.

Nye tider var på vej, vor trængsel var dog ikke forbi; men forventningen til fremtiden var stor. Afstemningen og genforeningen med Danmark vinkede forude, derom var der ingen tvivl. Det var noget, vi hørte om daglig. Vi børns forståelse for det kommende var nok minimal; men spændende var det, at høre om de forandringer, som ville indtræffe, når vi blev genforenet med gamle Danmark. 
Der er skreven megen litteratur om de 56 år under preussisk styre og overgangstiden indtil og om genforeningen. Når jeg senere som voksen, har læst om alt dette, forstår jeg udmærket den bitterhed, der herskede mod den tyske overmagt, der virkede krænkende og småligt over for alt dansk.

I vort lille samfund i Neder-Jerstal mærkede vi ikke, at der sådan til daglig var spænding mellem tysk og dansk. Der var nogle enkelte familier i vort skoledistrikt, der virkelig var tyske, og så var der nogle enkelte, der var det, vi kaldte hjemmetyskere. Ingen var dog mere tysk, end at Modersmålet var deres daglige avis. Vi snakkede alle sønderjysk, enten man var tysk eller dansk, det var vort daglige omgangssprog. Der var altså ingen, der var på krigsfod, alt gik i det store og hele fredeligt til. Alle var vidende om, hvor alle stod i det nationale spørgsmål.

Afstemningsdagen blev en mærkedag, som ikke glemmes af dem, der var med. Til trivialitet er beskrevet, at afstemningsdagen den 10 . februar 1920 oprandt med storm og regn. Tyskerne tolkede det på den måde, at der himmel weint. Danskerne, at der flød guld i brudens skød. Der var fra det gamle land sendt flag til uddeling. Vort hjem fik også tildelt et flag, som blev hejst fra morgenstunden, hvorefter far og mor begav sig til afstemningsstedet i Blankenhof. Da dagen var til ende, og resultatet blev gjort op, var der på dette afstemningssted 254 danske og 5 tyske stemmer. For hele Bevtoft sogn, hvortil Blankenhof hørte, var der 694 danske og 24 tyske stemmer. Afstemningen blev fejret overalt i landsdelen om aftenen. De fra Neder-Jerstal, der havde transportmuligheder, tog til forsamlingshuset i Bevtoft, hvor den tyske ørn skulle afbrændes.

I Neder-Jerstal samledes så mange, som æ pissel i Johansens gård kunne rumme. Det var fortrinsvis arbejdere og småkårsfolk, der her mødte op med hele familien. Hvert hjem medbragte naturalier efter bedste evne, så kaffebordet bugnede, som et sønderjysk kaffebord gør, når det er allerbedst. Der var tale, sang og musik. Det musikalske blev besørget af min far og to af mine ældre brødre på violin og harmonika. Det var en festaften, som blev et uudslettelig minde for deltagerne, og med min dengang ti livsår er aftenens fest prentet i min hukommelse.

Til dagen og festen hører også en hændelse, som berørte vor familie og satte et venskab overstyr. Hovedpersonen var min moster, som havde bopæl i Emden i Tyskland. Moster Kjestine var født i Rangstrupgårde i 1867. Som følge deraf var hun efter de regler, der var fastsat, stemmeberettiget i sit fødesogn Agerskov. Moster var rejst fra Emden over Hamborg og ankom til Over-Jerstal den 10. februar, altså 
på selve afstemningsdagen. Hun fortsatte med $æ$ kleinbahn til Galsted kro, hvor afstemningen fandt sted for Rangstrupgårdes vedkommende. Her skulle hun møde en skoleveninde, som hun gennem mange år havde vedligeholdt forbindelse med, og som nu havde inviteret hende til at overnatte og nyde gæstfrihed. Men det skulle gå anderledes. Efter et velkommen og nogle hjertelige ord spurgte veninden - hva ha do stemt Kjestine - veninden har måske fået anfægtelse af tvivl om min mosters sindelag.

Tvivlen blev til vished, svaret fra moster kom prompte - $æ$ ha stemt tysk. Uden et ord mere spyttede veninden på moster, vendte sig om, og et livslangt venskab var forbi for stedse. Man må medgive min moster, at det var ærligt og modigt gjort, at hun bekendte kulør. Hun var bleven tysk i det tyske, vel, det var en ærlig sag; men Nordslesvig var hendes hjemstavn, hun var opdraget på dansk. Storsind havde det været, om hun havde stemt dansk. Det havde hun intet tabt ved, tværtimod. Moster måtte altså finde sig et andet overnatningssted. Hun tog med toget til Neder-Jerstal og overnattede hos vor morfar; men for moster var dagens trængsel ikke forbi. Vi skulle jo alle til afstemningsfesten om aftenen. Vor mor forklarede hende, at hun var velkommen til festen; men ønskede hun ikke at deltage, måtte hun klare sig hjemme i selskab med kaffekanden. Moster valgte at bide i det sure æble, tog med til festen og fik en hædersplads ved siden af vor morfar Peter Lousen, der $\mathrm{i}$ dagens anledning bar sit dannebrogskors.

Hvordan festen har bekommet moster, er der nok ingen tvivl om; men hun tog det pænt og i stiv arm. Et par dage efter tog hun hjem til Emden, en oplevelse rigere, og måtte erkende, at hendes hjemstavn atter kom tilbage til Danmark.

Efter afstemningen og festdagene fulgte hverdagen, omstilling til de nye forhold skabte mange problemer, og flere kom til. Det blev en epoke, der krævede stor tilpasning både menneskelig og økonomisk, og som for mange var svært at klare.

\section{Min skoletid}

Jeg begyndte i Neder-Jerstal skole i foråret 1915. Jeg har slet ingen erindring om min første skoledag. Det skyldes nok, at før min skolegang var jeg daglig på skolens legeplads i frikvartererne, så det at skulle med ind i skoleklassen har nok ikke gjort større indtryk på mig.

Min sidemand i klassen var lærer Stäckers søn Oswald. Vi kom meget godt ud af det med hinanden, og til tider delte jeg broderligt min 
medbragte madpakke. Sådan set, var det jo ikke nødvendig, at jeg havde madpakke med. Jeg kunne jo smutte hjem i det store frikvarter, hvis sulten skulle overmande mig. Det er nok rigtig, at maden smager bedre i selskab med andre. Mine fedteklemmer var forøvrigt indpakket i en halv side af Modersmålet. Modersmålet kunne sandelig også bruges til andet end at bringe nyheder; klippet i passende stykker blev den også brugt et meget nødvendig sted.

Lærer Stäcker var enelærer. De større børn fik undervisning om formiddagen og de små om eftermiddagen; men jeg mener at kunne huske, at vi hen i året 1916 alle blev undervist om formiddagen. Det skyldes nok for en del, at lærer Stäcker også var kommuneforstander for Strandelhjørn og Neder-Jerstal. Denne bestalling, for det var det virkelig efter tyske forhold, krævede en stor del af hans tid, så efterhånden fik vi færre og færre undervisningstimer.

Skoleklassens udstyr var det nødvendige kateder og skolebænke. Der var den store fritstående tavle og en kugleramme til brug for regnekunsten. På væggen hang et verdenskort og et kort over Tyskland, desuden et par billeder, hvis motiv var fugle og dampskibe. Ja, så var der selvfølgelig også et billede af hans kejserlige majestæt. Kejserens fødselsdag 27. januar blev fejret med uddeling af »bom« og den schwartz-weiss-rote fane blev hejst på morgenstunden under skoleklassens bevågenhed. Skolen og stationen var forøvrigt de eneste i byen, der havde flagstang, men der var nok heller ingen andre, der følte trang til at markere dagen.

I 1917 var Tysklands forsyninger på alle områder ved at slippe op. Det gjaldt om at skaffe ersatz til vor kære Hindenburg og Ludendorf, så de kunne vinde krigen. Skolebørnene blev mobiliseret, dog til det mere fredelige. I sommerhalvåret 1917 og 18 blev vi en dag om ugen sendt til Strandelhjørnskov for at plukke bøgeblade og brændenælder, eftersommeren var det indsamling af kastanier. Det blev nu ikke til de store ting, især hvad angår bøgeblade; men vi gjorde vort bedste, så vi børn fra Neder-Jerstal skole er uden skyld $i$ at Tyskland tabte krigen.

I min skoletid havde vi også skoleudflugt. Den foregik umiddelbart før sommerferien. Den første udflugt, hvor jeg var deltager, var i 1917 og gik til Åbenrå og Varnæsvig. Vi startede tidlig om morgenen med hestevogn til Over-Jerstal station. Derfra med tog til Åbenrå. Vi blev stuvet ind $i$ en fjerde klasse - en sådan vognklasse fandtes $i$ de tyske tog - det var en vogn med træbænke langs siderne. Den åbne plads i midten var ståplads, der også tjente til anbringelse af de rejsendes bagage.

Da toget gjorde holdt på Rise station, kom en gammel mand ind $i$ 


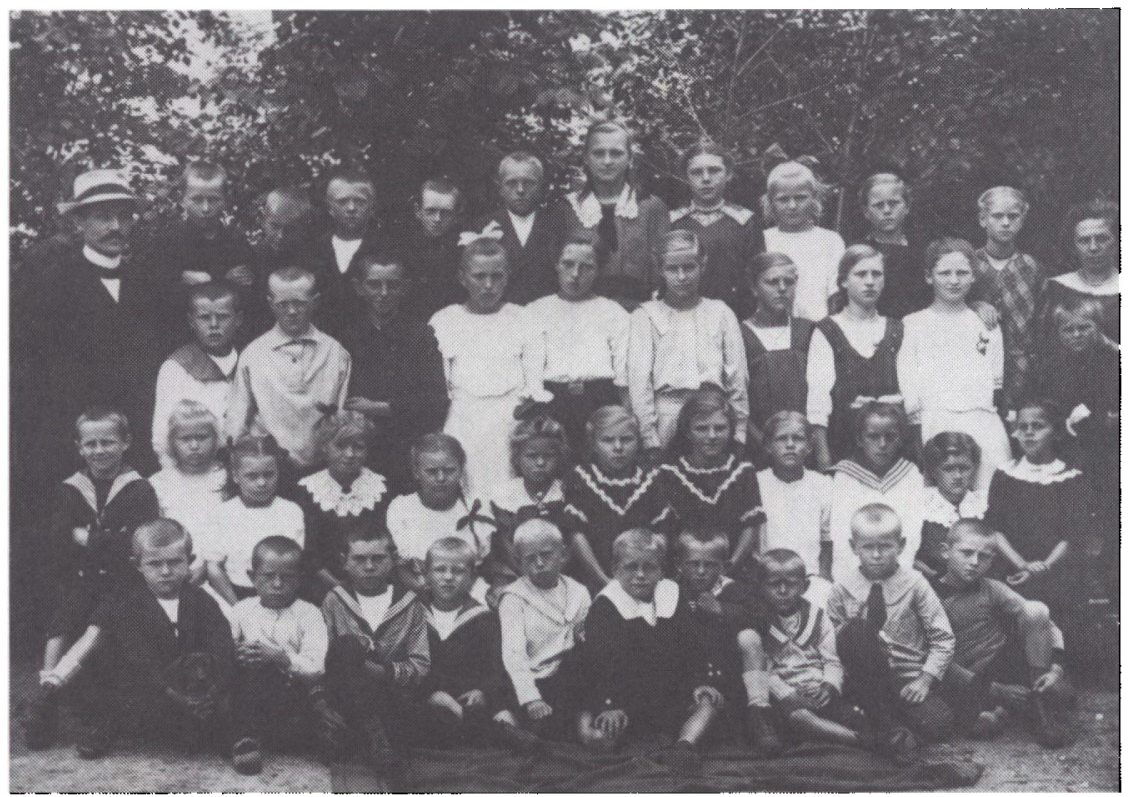

Neder-Jerstal skole ved larer Stäckers afrejse i 1919. Forfatteren ses overst til venstre.

kupeen. Om han nu var gammel, er jeg begyndt at tvivle på; men for en dreng på otte år er en på 40 til 50 år jo en olding, som går på gravens rand. Manden medbragte en spånkurv med trådnet over, hvori var anbragt 5 levende høns - bevar mig vel - sikken spektakel disse kunne lave. Der var baskende vinger, og hønsene trådte ovenpå hinanden. Vi børn var nok ikke uden skyld i dette hurlumhej, for vi stak en finger ned gennem trådnettet for at tirre dem. Den gamle mand - som måske slet ikke var gammel - tog det hele fra den gemytlige side. Der kom også et par mænd ind i kupeen med hver et par store sække. Vi erfarede på vor vej mod Åbenrå, at indholdet yar brændenælder, idet vi gerne måtte sidde på dem. Endnu flere entrede vor kupe med bagage af ubestemmelig art, så da toget startede fra Rise station, var det hele stablet som sild $i$ en tønde. Luften og duften $i$ kupeen var lidt blandet, trods det, at vinduerne var åbne $\mathrm{i}$ begge vognsider.

Ved ankomsten til Åbenrå spadserede vi fra stationen ned til havnen, hvorfra vi skulle sejle med en fjorddamper til Varnæsvig. Fjorddamperen var efter vor mening et temmelig stort skib. Vi sammenlignede skibet med det billede af en amerikabåd, vi havde hængende i skolens 
klasseværelse, og efter bedste skøn var denne damper her nok lidt mindre, for den havde kun én skorsten.

Ved udsejling fra havnen så vi flyvere, der kunne lande på vandet. Det var ganske uhørt, noget vi fra indlandet aldrig havde set. Vi havde forresten heller aldrig set en flyver lande på jorden. Sejlturen på denne skønne sommerdag var en oplevelse af de helt store, for de fleste den første sejltur, man oplevede. Ved ankomsten til Varnæsvig meldte sulten og tørsten sig. Den var næsten glemt under indtryk af alt det, man oplevede. Madpakkerne blev hevet frem af skotøjsæsken eller rygsækken, personlig havde jeg $\mathrm{i}$ dagens anledning lånt min fars madkasten, den, han til daglig medbragte sin madpakke og drikkelse i. Den var lavet af træ, på størrelse med en stor skoæske og kunne bæres over skulderen i en læderrem, så det var praktisk. Jeg havde hjemmefra fået overdraget 50 penning til at solde for. De blev hurtig formøblet ved $\mathrm{k} ø \mathrm{~b}$ af en herlig limonade formedelst 10 penning pr. glas; men min mor havde været forudseende, yderlig 50 penning var deponeret hos lærer Stäcker, så det varede ikke længe, før jeg henvendte mig i depotet. Det skal ikke skjules, at der ikke var en klink i mine lommer, da skoleklassen, de fleste både trætte og pengeløse, hen på aften nåede Neder-Jerstal.

Det havde været en uforglemmelig dag for mig, ja for hele klassen, så de følgende dage i skolen blev hele turen rekonstrueret, nok tilsat lidt digt, som ikke ville have kunnet stå for en nærmere prøvelse. Det var første gang, jeg havde kørt med det store tog og været så langt hjemmefra, alene det var en skelsættende begivenhed, som jeg dog måtte dele med de fleste af mine kammerater.

Der var meget at berette om til far og mor, om alt det man havde set $i$ dagens løb. Mine forældre og søskende hørte opmærksomt på min beretning. Måske dramatiserede og overdrev jeg lidt hist og her; men var det ikke tilgiveligt? Jeg tro nok mine forældre har været enige om, at de 10 groschen, der var ofret på turen, var givet godt ud.

Samme efterår havde skolen også en tur til Haderslev, her var befordringen med $æ$ lillebahn. Vi skulle $\mathrm{i}$ biografen, også det var en førstegangsoplevelse for de fleste af os. Vi så en spændende film med et værre leben. Der var en mand i filmen, der med lynets fart kunne klatre op af en tagrende, gå langs tagrygningen, foretage livsfarlige spring for at undslippe sine forfølgere. At manden slap levende fra alt dette er et guds under, men at han gjorde det, er rigtigt nok. Allersidst $\mathrm{i}$ filmen så vi nemlig, at manden spadserede nok så fornøjelig langs gaden.

Da krigen sluttede i 1918 søgte lærer Stäcker andet embede og 
flyttede i forsommeren 1919 til Isted i Sydslesvig med det resultat, at vi slet ingen undervisning fik før efteråret 1919, hvor skoledistriktets forældre på en eller anden måde fik ansat en dansk lærer, trods det, at skolevæsnet og al anden administration blev forvaltet af de preussiske myndigheder.

Inden jeg slutter beretningen om min tyske skolegang, skal jeg tilføje nogle ord om personen lærer Stäcker. Hans fulde navn var Heinrich Martin Friedrich Stäcker, født i Ditmarsken i 1888. Han var uddannet på Rendsborg seminarium, og hans første embede blev i Neder-Jerstal i 1910.

Lærer Stäcker var selvfølgelig præget af den uddannelse, man fik på de preussiske seminarier, kæft, trit, retning, og det blev også praktiseret i Neder-Jerstal skole. Uden for skolen havde Stäcker et godt forhold til befolkningen i skoledistriktet, og han har da også besøgt Neder-Jerstal flere gange efter sin afrejse herfra. Jeg har liggende foran mig, mens jeg skriver dette, et brev fra ham, dateret i 1960, hvor han boede i Altona som pensionist. I brevet giver han udtryk for sine følelser over for Neder-Jerstal og dens befolkning:

"Wohl waren fast alle Einwohner dänisch. Das schadete aber nicht. Sie waren immer sehr freundlich. Ich wäre gerne länger geblieben. Schweren Herzens gingen wir nach Holstein. Ja, Nordschleswig liebte ich und liebe es, so lange ich leber.

Lærer Stäcker fik et langt og godt otium og døde i 1970 hos en søn og svigerdatter i Bad Oldesloe.

Så nåede vi frem til 1. oktober 1919, hvor forældrekredsen på en eller anden mystisk måde, som det ikke har været mig muligt at få opklaret, havde fået en dansk lærer til at overtage undervisningen i Neder-Jerstal skole.

I forbindelse med lærer Larsens overtagelse af embedet, erindrer jeg en episode, som indtraf ca. en måned efter hans tiltræden. Der mødte en ung tysk lærer op i Neder-Jerstal skole og afgav den besked, at han skulle overtage undervisningen. Efter en kort parlamenteren og afvisning af hans krav, trak den unge lærer sig tilbage, og der blev ikke fra de tyske skolemyndigheders side gjort flere forsøg på at overtage undervisningen.

Lærer Johan Larsen fik en stor og krævende opgave overdraget. Han måtte begynde med os alle på første klassetrin, og selv måtte han til at lære at forstå vor sønderjyske dialekt. Det blev en dejlig tid, man glædede sig til hver skoledag, og det skyldes ikke mindst, at lærer Larsen havde god magæj (god måde) at tage børnene på. 
Det allerførste vi måtte igang med var at skrive latinske bogstaver, og det lykkedes på kort tid. Læsning gik også helt smertefrit. De fleste var fra hjem, hvor man var holder af de danske aviser Modersmålet eller Hejmdal.

Skoledagen begyndte med morgensang og bøn, derefter var der bibelhistorie $\mathrm{i}$ den første time $\mathrm{i}$ to af ugens dage. Timeplanen var yderligt opdelt i regning, skrivning, geografi og danmarkshistorie. En gang om ugen var der en sangtime, hvor man $i$ mangel af bedre benyttede et sanghefte, som var udgivet af margarinefabrikken Alfa i Vejen. Det var faktisk hele timeplanen for ugens seks dage; men starten var god, det var en god begyndelse på vort tilhørsforhold til Danmark.

Jeg fik ca. tre gode og lærerige skoleår hos Johan Larsen, og mindes ham som et fint og forstående menneske. Han var givet den nådegave at kunne leve sig ind i sønderjysk tankegang og væremåde. Han fandt også sin livsledsager i det sønderjyske, idet han indgik ægteskab med Kjestine Holm fra Neder-Jerstal. Lærer Johan Larsens gerning i NederJerstal blev forholdsvis kort, idet han afgik ved døden $\mathrm{i} 1932 \mathrm{i}$ en alder af 40 år og fik sit hvilested på Bevtoft kirkegård.

I eftersommeren 1922 måtte jeg sige farvel til Neder-Jerstal skole. Vi

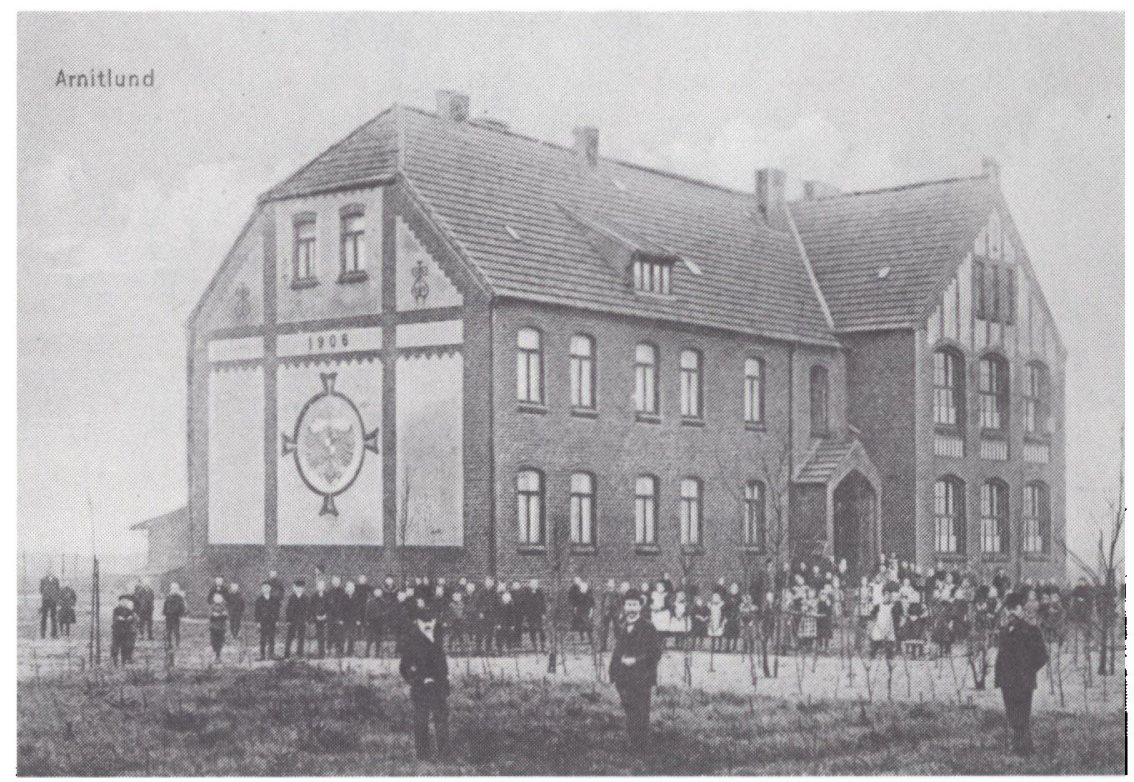

Arnitlund - Over-Jerstal skole. Foto 1908. 
flyttede fra vort hjem i Neder-Jerstal til Over-Jerstal. Som følge deraf måtte jeg skifte skole. Jeg begyndte i Arnitlund-Over-Jerstal skoles øverste klasse, hvor førstelæreren hed Johs. Larsen. Her fik jeg undervisning, indtil jeg blev konfirmeret i foråret 1924.

Johs. Larsen var en god lærer, men havde den opfattelse, - hvad jeg bagefter kan se, ikke skal komme ham til skade - at i timerne skulle der være fart over feltet. Det havde til følge, at ens hjerneceller hele tiden skulle rotere for højeste omdrejning. Hjemmelektierne kunne man ikke snyde sig fra. Jeg vil tro, at Johs. Larsen, hvis han nu ikke var blevet lærer, kunne være bleven en god toldembedsmand. Når en eller anden havde "glemt «, at der var noget, der hed hjemmeopgave, og samvittigheden som følge deraf var lidt flosset $\mathrm{i}$ kanten, ja så blev det uvægerlig bemærket af Johs. Larsen. Uha, den stakkels synder.

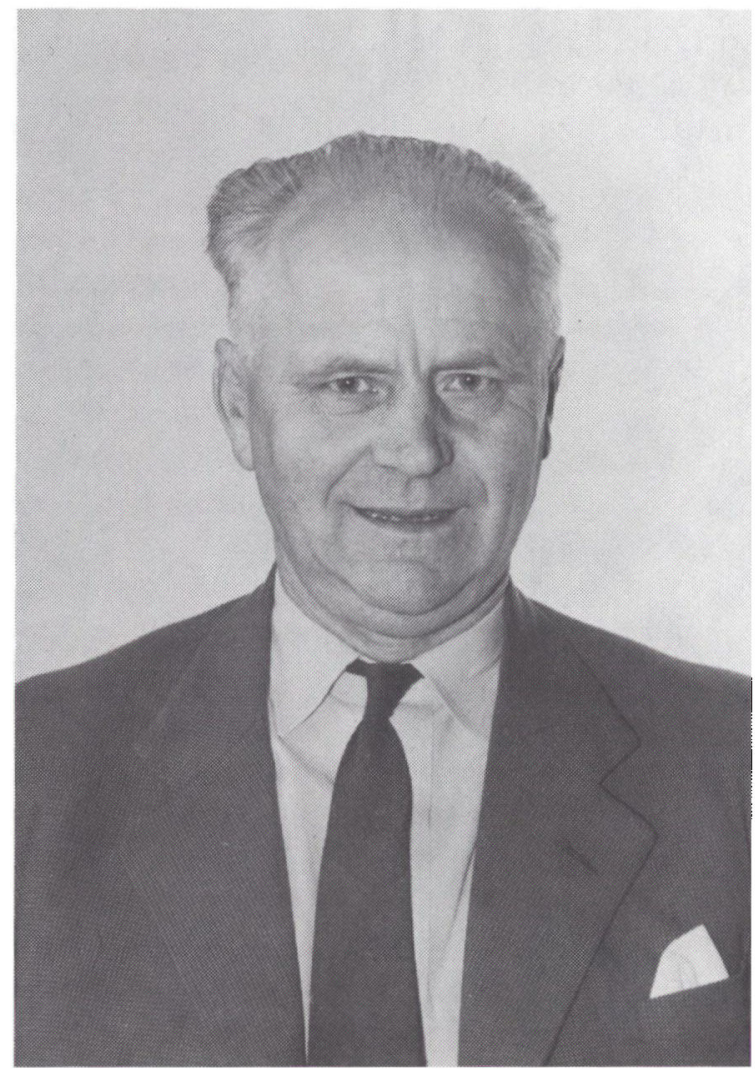

Larer Johs. Larsen, Arnitlund - Over-Jerstal skole, andenlarer her 1920-21 og forstelarer $1921-61$. 
Lidt spræl i timerne, f.eks. det at skyde med papirkugler efter pigerne blev ikke tålt. Det blev altid opdaget, fordi tøserne som regel hylede op. Eller vi drenge benyttede trappegelænderet til hurtig nedstigning. Kollektiv afstraffelse, ingen boldspil i det store firkvarter den dag. Der skal ikke herske tvivl om, at Johs. Larsen havde evne til at skabe sig respekt, også over for vi store 13-14 årige knægte; men jeg kan sige, at de fleste af os var glad for ham som lærer. Der blev ikke gjort forskel hverken på Per eller Poul, og til daglig gik det hele ganske gelinde.

Johs. Larsen var også en genforeningslærer og udøvede sin lærergerning i Arnitlund-Over-Jerstal skole til pensionsalderen, fik et langt otium og døde $i 1981$ i en alder af 89 år.

Jeg sætter ikke mit lys under en skæppe. Jeg syntes selv, jeg klarede mig hæderligt i skolen. Det med, at jeg klarede mig hæderligt, må lærer Johs. Larsen også have ment, idet han var af den mening, at jeg burde fortsætte skolegangen på katedralskolen i Haderslev. Den mening og tanke kunne jeg af fuldt hjerte tilslutte mig, idet det var min tanke, at jeg derefter ville på seminarium for at læse til lærer i folkeskolen.

Tanken måtte opgives; der var simpelthen ikke råd til at holde mig til bogen. Fars løn strakte ikke til dette, og ungdomsydelse eller studiestøtte kendte man ikke dengang. Det var en sinkadus, som skulle overvindes, og jeg blev ikke bitter, slet ikke, jeg erkendte situationen og tog den til efterretning.

Skæbnen ville, at jeg senere i livet i nogle år fik lejlighed til at berejse mange lande, fra Australien i syd til Norge i nord, som reparatør af iskremmaskiner. Jeg havde nok ikke oplevet denne del af verden, hvis jeg var blevet folkeskolelærer, så alt har nok skikket sig såre vel.

\section{Til stationsbyen}

Eftersommeren 1922 var familien flyttet til Over-Jerstal. Grunden til flytningen var, at det var mere centralt $\mathrm{i}$ forhold til min fars arbejdsplads.

Det, at vi skulle tage afsked med Neder-Jerstal, blev i og for sig ikke modtaget med den store begejstring. Vi børn skulle jo skifte skole og kammerater, men trods disse betænkeligheder, var der en vis spænding om det nye, som forestod. Tilpasningen til de nye forhold skete ganske smertefrit.

Skal jeg foretage en sammenligning mellem den fraflyttede og tilflyttede Jerstal, så var det den tilflyttede, der scorede de fleste points. Over-Jerstal var, hvad man forstår ved en rigtig stationsby. Her var 


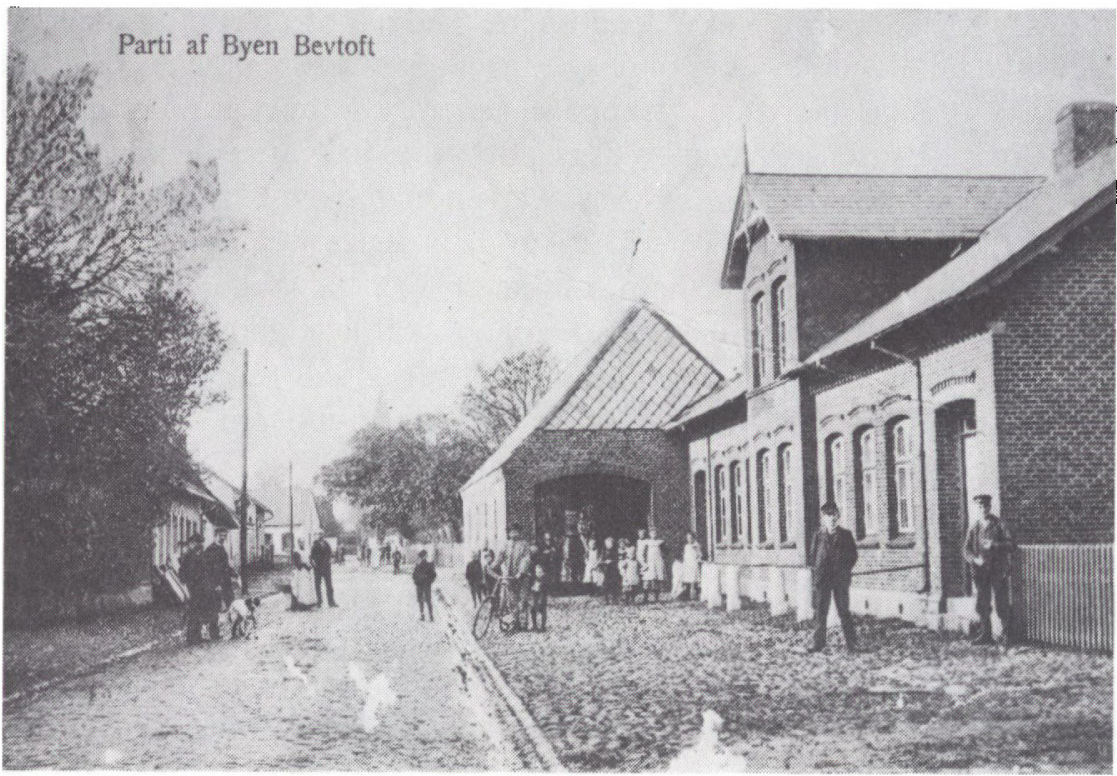

Bevtoft kro med den brolagte hovedgade foran. 1909.

både statsbane og amtsbane, der var posthus og forretninger, der var en kro og et hotel, en læge manglede ejheller, så det hele var lidt stadsmæssigt. Jeg foretog også en sammenligning med Bevtoft, som jo havde været vor sogneby. Skal jeg være helt ærlig - og det skal jeg jo så var Bevtoft ligesom lidt mere »fin«. Bevtoft havde en del forretninger, men på det område kunne Over-Jerstal nok hævde sig. Derimod havde Bevtoft en kirke, dertil en præstegård og så var der et forsamlingshus, hvad Over-Jerstal ikke havde. En væsentlig ting, der også placerede Bevtoft $\mathrm{i}$ den fine ende ved min bedømmelse, var, at et stykke af gaden gennem Bevtoft var brolagt. Det var sandelig ikke enhver by, der kunne prale med en sådan overdådighed. Nå, det var jo OverJerstal, vi var blevet bosat $i$, så alt det fine måtte lades ude af tankerne.

Over-Jerstals indbyggere var flest folk med jævne indtægter, for det store flertal tangerede mod den nedre ende. Der var smăhandlende og håndværkere, der var de ansatte ved bane og post, en del aldersrentenydere, som folkepensionister dengang blev kaldt. Der var også et betragtelig antal arbejdsmænd, der klarede sig ved tilfældigt arbejde. Standsforskel var der ingen grund til at pleje, og det mærkedes faktisk heller ikke. 
Livet i Over-Jerstal blev levet på det jævne i mere end en forstand. Byen var ikke et kulturcentrum. Borgerforeningen var den førende forening og det samlende midtpunkt, med ringriderforeningen på andenpladsen. Borgerforeningen var stiftet med det formål at skaffe byen gadebelysning, da elektriciteten kom til Over-Jerstal. Denne opgave blev klaret på tilfredsstillende måde. De ophængte lamper var placeret $\mathbf{i}$ god afstand fra hinanden. Der skulle spares på den dyre strøm, så $\mathrm{i}$ vinterhalvåret blev der slukket klokken 24 , og i de lyse sommermåneder blev det overhovedet ikke tændt. Borgerforeningen var arrangør af et årligt lottospil og et dilettantstykke, hvor overskudet gik til betaling af gadebelysningen. Når jeg tænker tilbage, var de opførte dilettantstykker nok i underkanten af det lødige; men det var altid succes. Det var nok kun et mindretal, der nogensinde havde set et teaterstykke, så der kunne foretages en sammenligning; men alt blev gjort i bedste mening.

Ringriderforeningen havde sin årlige ringridning omkring midsommer. Det var også en af årets hovedbegivenheder, som samlede et betragtelig antal festdeltagere fra byen og omegnen, samme forening afholdt ved fastelavnstid maskerade, begge fester med bal bagefter. Vinterhalvåret bød også på dansekursus. Danselærer Helsighoff fra Haderslev afholdt danseskole for børn og unge og de lidt ældre, der lærte man at være nobel, så man kunne begå sig på et dansegulv.

Jeg må ikke glemme æ mærken. Det var det helt store og tillige folkeligt $\mathrm{i}$ bredeste forstand, en hurlumhej, der både havde en fordag og efterdag med $æ$ mærkensdav $\mathrm{i} æ$ midt. Der var opstillet mange telte omkring L. I. Petersens hotel og købmandshandel. Der kunne købes både dit og dat, stort og småt. Der var alt, hvad øje og hjerte kunne begære. Der var blandt andet urkæder i det pureste guld, med garanti for ægthed og holdbarhed fra tolv til middag. Der var blikfløjte med kokkemandshoved og hundrede af andre ting, hvor efterstræbelsen blev begrænset af ens kontante formåen.

Det kunne gå livligt til sådan en mærkensdav. Det kunne blive lidt støjende, især hen på aftenen, når for mange punse var gledet gennem halsen; men så skaffede landbetjent Schmidt fra Hoptrup roen tilbage. Schmidt kom kørende på sin nimbus, den med kakkelovnsrøret. Schmidt var ingen streg i luften, tværtimod, han hørte til sværvægtsklassen, så der var ingen der kunne drømme om at trodse ordensmagten. Schmidt klarede alt på sin rolige og myndige måde, det var en helt undtagelse, når han brugte sin politistav.

Der foregik også andet, skal vi kalde det mere lødige aktiviteter. Der 


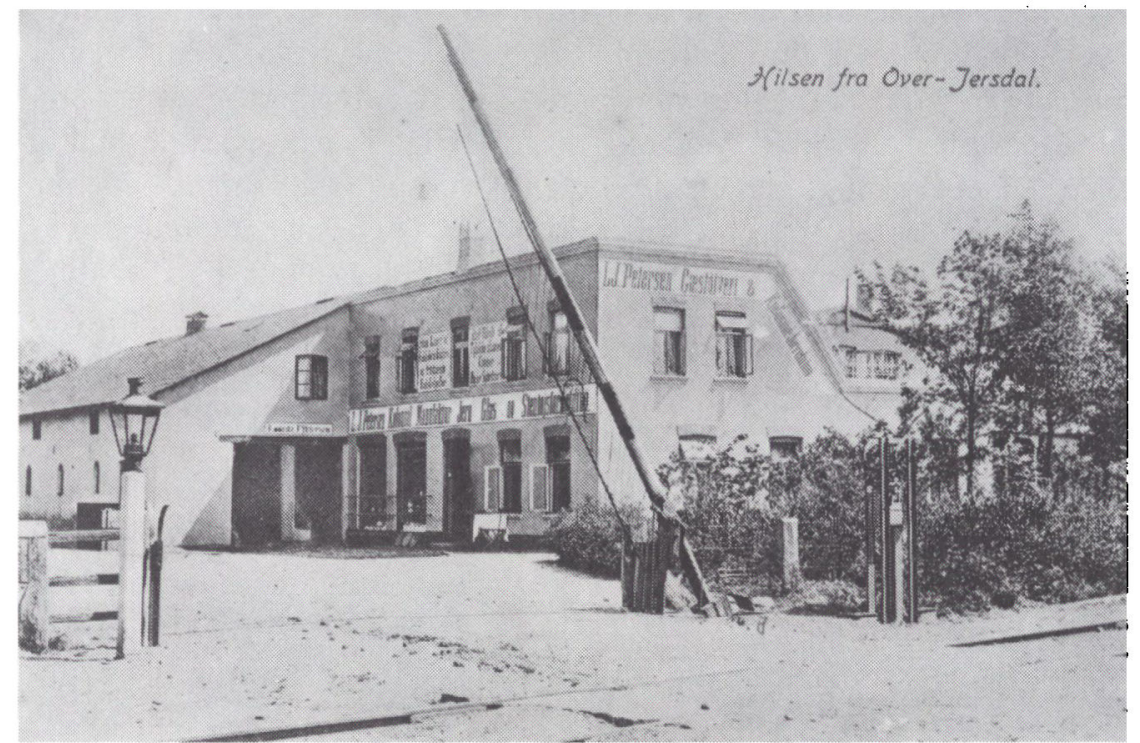

L. I. Petersens gastgiveri og kobmandsforretning i Over-Jerstal ca. 1912.

var indremissions kredse, der var afholdsbevægelsen, den havde loge $\mathbf{i}$ den gamle Arnitlund skole. Der var ungdomsforening og sangforening, som havde tilhold på Vedsted landbohjem. En såkaldt husflidforening, der havde træsløjd på programmet, havde mange medlemmer og samlede i vinterhalvåret både børn og voksne som udøvere. Af faglige foreninger mindes jeg kun arbejdsmandsforbundet, som var tilknyttet socialdemokratiet, andre partipolitiske foreninger tror jeg ikke fandtes i Over-Jerstal i de første åringer efter genforeningen.

Familiens bosættelse i Over-Jerstal skabte ikke større forandringer i vor tilværelse, alt blev som det var, dog med en svag antydning til det bedre, hvad angår økonomien. Det var, ligesom tilværelsen var blevet lettere, og mere trygge forhold var skabt efter genforeningen. Vi fik også efter krigen, én til to gange om året en stor pakke tøj fra en faster i Amerika. Dette tilskud af tøj pyntede vældig på budgettet.

Jeg havde straks ved vor bosættelse i Over-Jerstal fået to budpladser, hos en købmand og en bager, og en ugentlig eftermiddag var jeg beskæftiget hos en bondemand på Thorsbjerg, hvor jeg skulle køre til møllen eller gå husbestyrerinden til hånde. Da jeg skulle konfirmeres, var det en stolt dreng, der havde sparet så meget op, at han selv kunne 
betale sit konfirmationstøj og tillade sig at vælge og vrage, hvad der nu passede ham bedst.

De to skoleår jeg fik i Over-Jerstal var en god tid, så det var ikke helt uden vemod, jeg tog afsked med skolen i foråret 1924 .

\section{Min læretid i Vojens}

Når jeg skal tegne et billede af Vojens, som den så ud, da jeg i 1924 begyndte som lærling hos Brdr. Gram, må jeg gøre det ud fra det sammenligningsgrundlag, jeg havde i Neder- og Over-Jerstal. Stort andet havde jeg ikke at holde mig til i min, dengang begrænsede verden.

Vojens var en lidt større stationsby; det kunne ikke bestrides. Der var statsbane syd og nord og til Haderslev. Der var amtsbanen øst og vest og en privat bilrute, der tre gange daglig besørgede person- og posttrafikken over Bevtoft til Toftlund, så Vojens måtte betragtes som et ikke ubetydelig knudepunkt. Nogen skønhedsåbenbaring var byen ikke, og omgivelserne omkring den var stort set uden beplantning, så det hele virkede lidt barsk og koldt.

Vojens som stationsby var for størstedelen opbygget i tysk tid. Bebyggelsen strakte sig på begge vejsider langs landevejen Haderslev-Ribe, begyndende ved kirken i øst og omtrent ud til pottevejen i vest. Dertil kom nogle enkelte sidegader, eller rettere sideveje med spredt bebyggelse. Lad mig ikke glemme at fortælle, at Vojens sandelig også havde et stykke brolagt gade, nemlig fra hotel Pauli og ned til amtsbanestationen.

Statsbanen var skillelinien for den østlige og vestlige bydel, der befolkningsmæssigt var nogenlunde lige store. Statistikken oplyser, at 1. januar 1925 var Vojens befolket af 1105 sjæle, så man vil forstå, at næsten alle kendte alle. Vojens voksede støt i de kommende år. Der blev bygget et slagteri, som kom til at beskæftige et betydelig antal slagteriarbejdere.

Der var også efter genforeningen bygget en kalkstensfabrik umiddelbart vest for bygrænsen. Den skabte beskæftigelse til et antal arbejdsmænd. Brdr. Grams maskinfabrik var den største arbejdsplads i byen med ca. 50 ansatte. Statsbanen og amtsbanen samt postvæsnet havde også et temmelig stort personale. Så var der småhåndværkere og forretninger i næsten alle brancher, så i det store og hele kunne Vojens ikke regnes for en stillestående by, hvad den senere udvikling også har bekræftet. 
Selve dagliglivet $\mathrm{i}$ byen adskilte sig ikke væsentligt fra normen. Aktiviteter $\mathbf{i}$ foreningsliv, som jeg vil tro var under middel, foregik på de to hoteller, hotel Pauli og hotel Vojens. Vojens havde i tysk tid været skarpt delt op i dansk og tysksindede med overvægt af sidstnævnte, så et samlet foreningsliv og kulturel aktivitet havde ikke fundet sted, og der gik en del år, inden dette faldt på plads, og Vojens fik indhentet det forsømte.

Når der gik nogle år, inden Vojens på dette område fandt sit ståsted, skyldes det nok for en del, at et mindre antal tilflyttere nordfra med en vis dominans kun blandede sig med et bestemt klientel af Vojens borgere. Hvad der var uden for denne cirkel, undså man sig ikke for at betegne som den lavere klasse, og der er ikke tvivl om, at det skulle forstås både som penge og mangel på kundskaber. Cirklen var ikke jævn med det jævne, kredsen manglede lidt takt og tone; men navnene var ejheller at finde i den blå bog, det var en kreds om »five o'clock the«. Dermed være alt sagt, og lad det så ligge.

Vojens modtog også efter genforeningen folk nordfra, som gjorde en god indsats, her tænkes særligt på de lærere, som blev knyttet til folkeskolen. En af dem, jeg kom til at sætte stor pris på, var lærer Dalgaard, som foruden sit lærerkald også var bibliotekar på det lille bibliotek, som var indrettet i tilknytning til skolens lokale. Dette bibliotek blev et mekka for mig. Bøger var for mig både en viden og en nydelse. Jeg blev en flittig låner, aldrig havde jeg haft adgang og mulighed for et så alsidigt udbud af læsestof.

Jeg begyndte med at læse drengebøger, det havde jeg jo ikke haft mulighed for i min drengetid; men lærer Dalgaard har nok syntes, at jeg skulle have noget læsestof med lidt mere kød på, så han gav mig gode tips og satte mere system i min læsning. Jeg tog fat på Martin Andersen Nexø, Jeppe Aakjær, Johan Skjoldborg og mange flere af den tids forfattere. Historie og rejsebeskrivelser blev mig også en kær hobby. Med dette som baggrund og med krum hals og sidevind gik jeg derefter igang med litteratur af Henry George, Karl Marx, Adam Smith, Malthus, Darwin, L. V. Birck for at nævne nogle af de vigtigste; men der var mange flere på mit repertoire. Disse mænds bøger var nok hård kost for en syttenårig, meget gik nok hen over hovedet på mig, og en hel del blev slugt råt, så efter at jeg har taget til i alder og bedre har kunnet fordøje den slags, har fornyet læsning medført, at jeg nok er mere kritisk og ikke så modtagelig for et hvilket som helst postulat.

Foranstående var et lille billede af Vojens, og nogle af de mennesker jeg mødte $\mathrm{i}$ mine læreår. Den gennemgik $\mathrm{i}$ de følgende år en rivende 
udvikling, og det blev i Vojens, jeg fik min gode arbejdsplads i næsten alle mine aktive år.

Det var efter min afsked med skolen og min konfirmation $\mathrm{i}$ foråret 1924 lykkedes at få en læreplads hos Brdr. Gram som blikkenslager og kobbersmed. Det var egentlig ikke det, man forstår ved blikkenslagerarbejde, der blev lavet på min afdeling. Det var blik og kobberarbejde til mejerier såsom mælkekar, mælkekøler, pasteuriseringsapparatur, fortinning af transportspande, i øvrigt alt hvad der hørte til et fungerende mejeri.

Jeg mødte 2. maj ovennævnte år. Dagen husker jeg udmærket, det var en skøn forårsmorgen, jeg cyklede til Vojens for at begynde på min $4 \operatorname{og} 1 / 2$ årig læreplads.

Jeg var nok en smule beklemt ved tanken om alt det nye, som jeg skulle stifte bekendskab med, men alt forløb udmærket. Min nærmeste overordnede blev Jørgen, som indtil min tiltrædelse havde været yngste lærling, men nu rykkede op i en højere rangklasse.

Af Jørgen fik jeg at vide, at der var visse pligter og regler, som man som yngste lærling ubetinget skulle iagttage. Hakkeorden skulle respekteres, derom kunne der ikke diskuteres. Jørgen gav en karakteri-

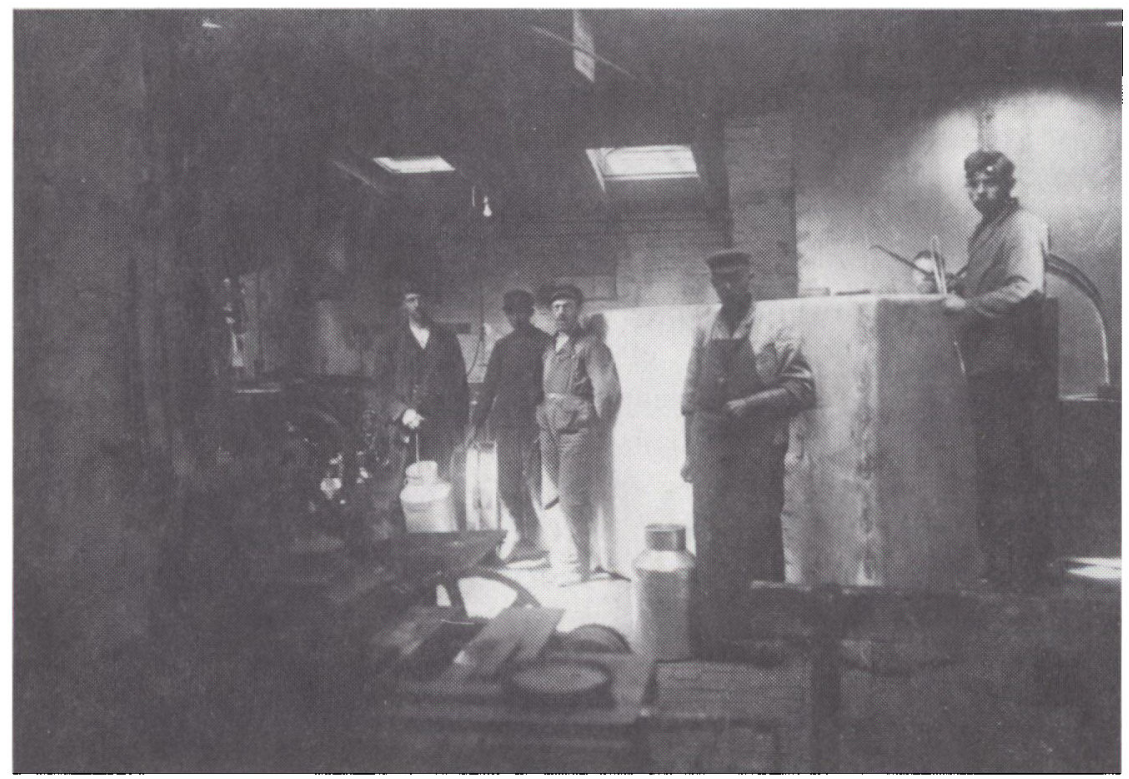

Interiør fra Brdr. Grams blikkenslagervarksted $i$ Vojens 1926. Fabrikken, der stadig fremstiller koleteknik, var indtil 1946 den storste maskinfabrik $i$ Sonderjylland. 
stik af hver enkelt svend, hans væremåde og hvorledes han iøvrigt skulle omgås og betjenes, herunder tiltaleform, som for de flestes vedkommende var De, og Hr. Jørgen informerede mig om, til hvem af svendene der skulle hentes øl i det nærliggende øldepot henholdsvis formiddag eller eftermiddag, om øllerne skulle hensættes $i$ en spand koldt vand til afkøling, eller de kunne konsumeres, som de var ved levering.

Der var også forskellige småfiduser, som det var nyttigt at have kendskab til, blandt andet det, at kom man et par minutter for sent på arbejde, kunne man stemple to gange på kontroluret, så ville overstemplingen ikke kunne aflæses. Det var nu en overtrædelse af reglementet. Det var det derimod ikke, når man gjorde sin entre på lokum og med et velrettet spark på bræddesiden gjorde rotterne opmærksom på, at nu skulle man forrette et nødvendigt ærinde.

Jørgen forklarede også, at på et eller andet tidspunkt i den nærmeste fremtid skulle man gennemgå et ritual for at blive betragtet som rigtig læredreng. Ritualet ville blive eksekveret af et par ældre læredrenge, der beordrede den ny lærling op på et bord i frokoststuen, hvor han liggende på ryggen og under beskuelse af de øvrige lærlinge, blev undersøgt, om det, der var under bæltestedet var et mandfolk. Gøre modstand mod denne undersøgelse ville være nytteløs. Offeret tog som regel del i ceremonien uden at gøre modstand, de fleste tog det også pænt og fra den gemytlige side.

Jørgen var en god kammerat - det var de fleste - og der gik ikke mange dage, så var jeg helbefaren i min rolle som yngste lærling, og jeg havde indtryk af, at jeg udførte mine pålagte pligter til fuld tilfredshed.

Svendene var af vidt forskellig observans, det skal svagt antydes; men de kunne deles i to hovedgrupper. Der var den faste stab, som var gift og hjemfaren og straks efter arbejdstid gik hjem til lillemor og ungerne. De lavede ikke det store spræl, men nøjedes med, efter tradition, at konsumere en pinse- og julebajer. Så var der de mere "løse«. Det var dem, der blev antaget tidlig om foråret, når travlheden satte ind. Nogle af dem var rene børster og forsvandt hurtigt efter nogle dage eller ugers arbejde. Landevejen var for dem det frie liv. Nogle enkelte mødte trofast op hvert forår og holdt ud, til den travle periode var slut hen på sommeren. Én af dem, der mødte op, næsten på dato og klokkeslæt var Ravn Rasmussen. Han var en mand på omkring de 60 år og en meget dygtig blikkenslager. Han blev altid budt hjertelig velkommen af mester og kollegaer, ja også af vi læredrenge, for vi satte stor pris på hans væremåde. Han havde gjort Europa i sine yngre dage, 
men nøjedes nu med de hjemlige græsgange. Han havde gode fortælleevner, så det var interessant at høre om hans mange oplevelser ude i den store verden.

Ravn Rasmussen mødte altid op i blåt cheviottøj. Han havde en velgører, der var ostehandler i Vejle, her blev han ekviperet én til to gange om året, alt efter behov. Tøjet var både søndags- og arbejdstøj, så når han hen på sommeren rejste fra os, var både tøjet og den stive knækflip lidt flosset $\mathrm{i}$ kanten. Her må jeg indskyde, at knækflippen ved arbejdstidens begyndelse blev hængt op på et søm over arbejdspladsen og ved fyraften igen prydede ejermanden efter at have fået en lettere rensning med spyt på en tvistklud. Hans ugeløn var, når kost og logi var betalt, omsat $i$ våde varer. Det var hans måde at leve livet på, og man havde indtryk af, at sådan passede det ham udmærket.

Et par andre indfandt sig også hvert forår. Det var røde Frederik og Carl fra Fredericia. De blev som regel det meste af sommeren, også hos dem bestod kosten mest af flydende varer; men man havde aldrig indtryk af, at de var berusede, de var, som de selv udtalte "gewohnt«. Carl var den mest markante af de to, han kunne uden at blinke servere en løgn, der var så tyk, at man kunne hænge sig i den. Carl blev senere en respektabel ægtemand, ja sågar formand for fagforeningen $i$ sin hjemby. Det skete dog ikke uden en vis modstand, så da valget var en kendsgerning, sendte oppositionen et telegram til hovedforbundet i København - Gud bevare Fredericia afdeling - det er også sket, og Carl blev en god formand. Vi havde endnu en Carl, som var på værkstedet $\mathrm{i}$ flere år. Han var et godt menneske $\mathrm{i}$ sind og skin. Han havde opholdt sig i Sønderjylland siden genforeningen og havde her haft forskellige arbejdspladser. Han var levende interesseret $i$ ungdomsarbejde, især vandrebevægelsen. Han måtte opleve skuffelse i sit ægteskab, så livet blev for ham ikke det bedste; men han tog livet, som det formede sig, uden at klage. Han fortalte gerne om, da han faldt ned fra sin arbejdsplads på Rise kirketårn, og måtte køres i en kassevogn liggende på et knippe halm til sygehuset i Åbenrå, sygeambulance var endnu ikke taget i brug i Sønderjylland. Carl var født i Horsens, hvor hans familie også var bosiddende; men hans ønske var, at få sit sidste hvilested i sønderjysk jord. Dette hans ønske blev også opfyldt.

Så var der Jonas, hans efternavn husker jeg ikke, han var hypokonder, det er ganske sikkert. Han mente selv, han gik på gravens rand, endskønt han ikke var fyldt de 30 år. Vi læredrenge holdt liv $i$ ham med kruschensalt og en eller anden slags piller, som jeg ikke husker navnet på. Hver fredag blev én af vi læredrenge sendt på apoteket, og 
formedelst fire kroner fik vi både kruschensalt og piller. Vi drenge fandt dog ud af, at kruschensalt kunne vi købe 20 øre billigere hos købmand Sørensen på hjørnet af Højgade; men vor salgspris til Jonas forblev den samme som fra apoteket. Jonas fik et langt liv; men vi læredrenge havde jo også gjort vort bedste for hans helbred.

Der kom i min læretid mange "løsgængere« på besøg i værkstedet. De var evig på valsen, og kom for at få en skilling af kollegaerne, hvad de som regel også fik. Nogle havde lidt skibbrud på et eller andet, andre havde bisselæder i sålerne. Fælles for dem alle var, at de gennemgående var velfornøjet og tilfreds med deres tilværelse; men lad mig tilføje, måske var det kun udvortes, hvem ved hvad der gemte sig bag facaden?

Jeg var hurtigt faldet til på værkstedet og kan med fuld ret sige, at jeg glad og tilfreds tog afsted på arbejde hver morgen.

Min læretid var ikke uden økonomiske ofre for mine forældre. Jeg boede hjemme, om sommeren cyklede jeg til Vojens, om vinteren benyttede jeg toget. Det første læreår var lønnen 10 øre pr. time, stigende til 20 øre i sidste læreår. Det var jo ingen Hollywoodgage, og så var det på egen kost og logi. Læremesteren betalte sygekasse og teknisk skole. Jeg afleverede de fire kroner hver uge til min mor; så var

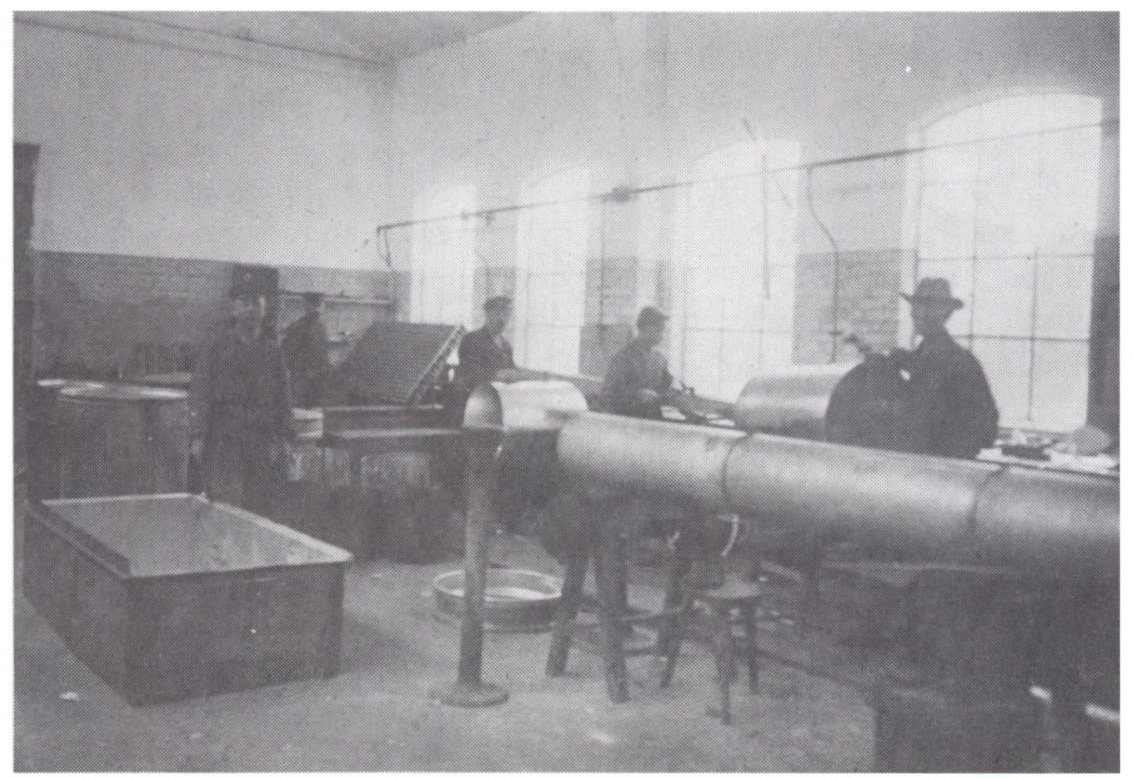

Interiør fra Brdr. Grams kobbersmedevarksted 1926. Forfatteren ses som nr. to fra højre. 
der 80 øre til lommepenge. Af dem ofrede jeg, så at sige, hver uge de 25 øre til pålæg til min daglige madpakke. Pålægget blev købt på slagteriudsalget i Vojens og bestod af ukurante stykker, det vil sige, noget der ikke var skåret i pæne skiver på pålægsmaskinen. Varen var sandelig frisk og god, så der var rift om at kapre sig for en 25-øre. Jeg var altid heldig; men det manglede da også bare, bestyrerdamen var fra Neder-Jerstal, så vi var bekendte, og mit indkøb gav altid en god stor pakke, så der var pålæg til hele ugen.

Jeg konstaterede med glæde, at min økonomi blev væsentligt forbedret i mit andet læreår. Der blev givet mig mulighed for i nogle af arbejdstimerne at arbejde på akkord, så til tider kunne min timeløn være fordoblet, og det blev endnu bedre det sidste halve år af min læretid, idet der blev tilstået mig halv svendeløn. Jeg fik også i mit andet læreår en ny cykel ved firmaets hjælp. Flot cykel, pris 102 kroner, som jeg måtte afdrage med det akkordoverskud, der var udover ugelønnen, så da $3 / 4$ år var gået var den kvit og frit. Jeg var vældig godt tilfreds med min læreplads, og det skal siges, at ville man lære noget, var mulighederne gode, allerede i andet læreår blev man en del af tiden sat til selvstændigt arbejde under mesters tilsyn.

Det var den almindelige mening blandt bedre vidende, uden for fabrikken, at Brdr. Gram havde for mange lærlinge og for få svende til at lære fra sig; men denne antagelse var ganske forkert. Det, at en lærling blev sat til selvstændig arbejde under mesters tilsyn, forpligtede og gav et ansvar, som man gerne ville honorere. De fleste fik, når vilje var tilstede og en tiltro til sig selv, en god håndværksuddannelse, eller sagt med andre ord - viljen til at ville, giver evnen til at kunne.

Arbejdstiden var 48 timer, fordelt på de seks af ugens dage, lørdagsfri kendte man ikke dengang. Ud over de daglige otte timer kom oprydning af værksted efter fyraften. Dertil skal dog siges, at mester var meget large på dette område. Som regel fik vi læredrenge lov til at foretage dette før fyraften. Der var dog undtagelser. Vi store lømler lavede af og til spilopper, både store og små, og ikke altid af uskyldig art. Vi var ærlig talt ikke altid søndagsskolebørn. Resultatet af vor mere eller mindre gode opførsel blev belønnet med, at der skulle gøres rent $\mathrm{i}$ værkstedet efter fyraften. Mod denne nederdrægtige tortur eller straf, eller hvad man nu vil kalde det, havde vor kyllingehjerne opfundet et middel, der dog kun kunne bruges i vinterhalvåret, når vi skulle på teknisk skole. Vi skulle om vinteren fra mandag til fredag møde på teknisk skole kl. 18. Blev det nu pålagt os at gøre rent efter fyraften, blev tiden trukket ud, der blev gjort »grundigt« rent. Resulta- 
tet var, at vi kom for sent til skolen, omkring en halv time, til tider lidt mere. Vi havde en god undskyldning, mester havde pålagt os rengøring af værksted efter fyraften o.s.v. - o.s.v.

Forstanderen sendte en seddel til mester, at d'herrer skulle møde rettidig, og det var lige det forventede. På den måde slap vi for rengøring efter fyraften. Skete det alligevel, at mester efter en sort dag havde en anden mening, var vi frække nok til at gøre opmærksom på, at huskede vi ret, havde forstanderen for teknisk skole sendt brev til mester angående vor rettidige tilstedeværelse på skolen. Var fanden ikke løs i Laksegade, så var han det i værkstedet. Mesters reaktion var mildt sagt - lad mig ikke næune de ord, der kom fra mesters mund - de var rødglødende, papiret her ville komme i brand. Men lad det også være sagt, mester var god nok, han var retfærdig i sine afgørelser. Mange gange tog han os læredrenge i forsvar, når en eller anden svend lod sin galde flyde over os, eller selve fabrikanten mente, at vor opdragelse lod en del tilbage at ønske.

Én af de ting, der brød hverdagen, var, når fabrikken havde den årlige udflugt. Hele personalet med kone og børn og dem med kæreste og dem uden var deltagere. Udflugten var altid i højsommeren og stedet var Kelstrup strand. Det var et festligt skue, når ekstratoget startede fra Vojens amtsbanegård. Toget bestod af en motorvogn og to tilkoblede vogne, så kunne alle være anbragt. Jeg mindes, at det altid var strålende sommervejr den lørdag eftermiddag, udflugten løb af stablen. \#ren tiltog fabrikant Aage Gram sig i al beskedenhed. Muligvis har han haft en snak med en vejrprofet god tid forud, eller vejret var bestilt hos meteorologisk institut, hvem ved.

Der vankede kaffe og kager på firmaets regning ved ankomsten til Sølyst badehotel. Derefter var der leg og underholdning for børnene. De unge kunne spadsere på kærlighedsstien, eller der var mulighed for at foretage en svømmetur. Aftensmaden bestod af medbragt madpakke og $ø l$ for egen regning. Derefter var der dans, og hjemturen startede ved 24 tiden, lidt mere højrøstet end udrejsen.

Jeg har et særligt minde fra det første år, jeg var deltager. Da det var en lidt pinlig episode, fortalte jeg kun om denne til min gode kammerat Jørgen, og han lovede, at det betroede aldrig skulle komme uden for hans ribben, hvad det heller ikke gjorde.

Jeg var inviteret af en af svendene til at spise aftensmad sammen med hans familie. Hans kone havde virkelig medbragt en god fyldt madkasse. Jeg skal ikke gå i enkeltheder; men én af de ting, den indeholdt, var tomater. Jeg havde aldrig smagt tomater, og beskeden var jeg bestemt 
ikke, så jeg udsøgte mig den største, der fandtes på bakken. Bevar mig vel, det var det mest rædselsfulde, jeg nogensinde havde sat mine tænder $i$, og hvorledes skulle jeg nu klare den situation uden at fornærme mine værtsfolk og uden at afsløre min oprigtige mening om disse røde tingester.

Jeg lagde min hjerne lidt i blød, og mens jeg tænkte, faldt tomaten ud af min hånd og ned under bordet. Jeg hjalp nok selv lidt til, at den smuttede. Mine flinke værtsfolk mærkede intet til »uheldet« og fik det aldrig at vide.

Inderst inde var jeg lidt stolt af min konduite og lod det skinne igennem over for kammerat Jørgen; men det lod ikke til, at han var imponeret af, at jeg var så snarrådig.

Den årlige udflugt fortsatte min læretid ud, men derefter blev fabrikkens personale så talrigt, at der ikke var lokale i passende afstand fra Vojens, der kunne rumme og beværte os.

\section{Så kom svendetiden}

Så oprandt dagen og tiden den 31. oktober $1928 \mathrm{kl}$. 17. Jeg var nu udlært håndværkssvend, stod med et pænt svendebrev i hånden affattet ikke alene på dansk, men også på tysk og engelsk. Det attesterede, at jeg havde udstået min læretid som blikkenslager og kobbersmed og dertil en pæn anbefaling underskrevet af fabrikant Aage Gram med hans karakteristiske håndskrift.

Det var alt meget pænt; men samtidig fik jeg at vide, at arbejde var der ikke noget af. Det kom nu ikke som nogen overraskelse. Måneder i forvejen havde der i min afdeling kun været beskæftigelse til mester og en svend og et par læredrenge. Den ældre svend måtte også se sig arbejdsløs, så det var rent ud sagt jammerligt. For den ældre svend var det et hårdt slag at stå uden arbejde efter flere år på fabrikken. Jeg var jo ung og uden forpligtelse; men selvfølgelig var det ikke det, man havde ventet, at skulle til arbejdsløshedskassen og hæve to kroner pr. dag i understøttelse. Denne understøttelse var man berettiget til i 100 dage i løbet af et år, derefter var der kun den kommunale hjælpekasse, hvor ydelsen var efter skøn, og vel at mærke, når der var penge i kassen, hvad der ikke altid var. Indtægterne, både hos bønder og arbejderne var små, så skatterne strømmede ikke ind i kommunens kasse. Mange arbejdsløse måtte friste tilværelsen på landevejen og gå fra dør til dør for at sælge de arbejdsløses blad »Livets Kamp« for en 25-øre.

Det gik for mig bedre end ventet. Kun tre uger varede ledigheden, så 


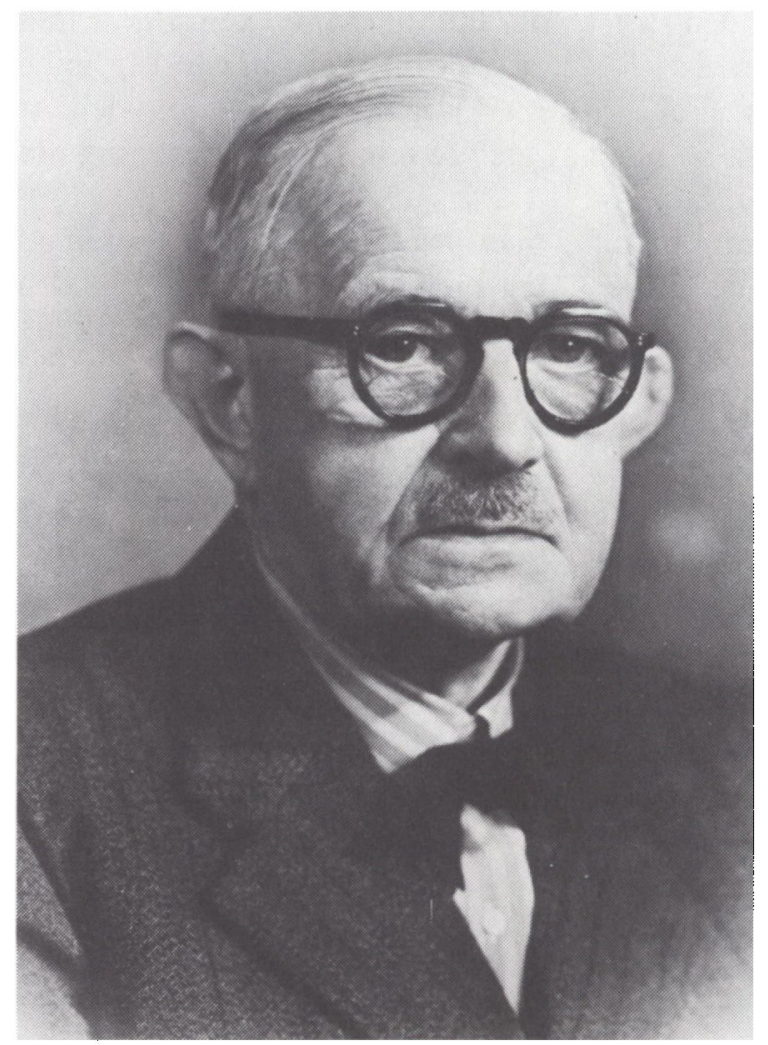

Fabrikant Aage Gram (1879-1957). Sammen med broderen Hans Gram skabte han den store fabriksvirksomhed $i$ Vojens: Brodrene Gram, en specialfabrik for koleanlag og iskremmaskiner.

var jeg, og den gamle svend også, på vor gamle arbejdsplads og for mit vedkommende strakte arbejdet, med korte afbrydelser, næsten helt til jeg tog på højskole i vinteren 1930-31.

Jeg glemte at fortælle, at da jeg blev svend, havde jeg selvfølgelig fået anskaffet mig en bowlerhat og spadserestok. Det hørte sig til for en rigtig håndværkssvend, og det hjalp på anseelsen, både over for piger og andet rak. Jo, ud $i$ egen indbildning kendte man sit værd.

Lad mig fortælle om højskolen. Jeg havde længe haft et ophold på højskole i tankerne; men på en måde var det jo sin sag at opgive sit arbejde. En månedstid, før et semester begyndte, fik jeg igen fyreseddel, og så var sagen klar.

Jeg søgte optagelse på Esbjerg arbejderhøjskole og fik besked derfra, at jeg kunne møde 3 . november 1930. Jeg søgte amtet om tilskud til opholdet og fik bevilliget $30 \mathrm{kr}$. pr. måned. De strakte jo ikke til, men jeg havde sparet op med den tanke i baghovedet, at de skulle bruges til 
et ophold på en højskole, når lejlighed bød sig, så jeg klarede det økonomiske med en streng sparsommelighed.

Det blev for mig en uforglemmelig vinter. Jeg sugede al den lærdom og viden til mig, som jeg kunne fordøje og lidt til. Skolen var belagt med ca. 100 elever. De fleste var taget på højskole på grund af arbejdsløshed. Det var en broget skare, der var samlet under ét tag, alle afskygninger af politiske meninger, fra det yderste højre til det yderste venstre. Der var royalister af højeste potens, republikanere, der ville have republik indført $\mathrm{i}$ den følgende måned hvis ikke før. Så var der grundtvigianere, der havde Grundtvig øverst på piedestalen. Dem kunne jeg tage en dialog med, idet jeg havde sat mig en del ind $i$ Grundtvigs forfatterskab og hans virke i den grundlovgivende forsamling. Der var en enkelt, som højlydt og gerne proklamerede, at han var mormon. Jeg tror nu ikke, at troens grundlag var det væsentligste, men derimod at med troen fulgte et lille harem. Der var en lille klike, men for at de forkerte ikke skal føle sig under mistanke, så lad mig fortælle for ikke at gå nærmere på - at de var hjemmehørende øst for storebælt. De vidste alt om her og der og alle vegne og havde altid færdigsyede og hjemmestrikkede meninger om alt mellem himmel og jord. Jeg havde nær glemt afholdsfolkene, de var tro disciple af Larsen-Ledet; men de var sandelig ikke de ringeste, og jeg kunne også følge dem et langt stykke.

Tilhængere af den personlige friheds værn var modstykket til afholdsfolkene, og de var nok flest. Det kunne gå livligt til, når de to parter mødtes i foredragssalen en aften til en ublodig duel. Et af de tilbagevendende hovedemner var ølporten. Her skylder jeg en forklaring. Da skolen blev bygget, havde Carlsbergbryggerierne skænket en portal, der var opført ved indgangen til skolens grund. Den var i allerhøjeste grad en torn i øjet på de rettroende afholdsmænd, og de lagde ikke skjul på, at de gerne så, at den væltede førstkommende nytårsaften. Jeg var enig med dem. Skolen og arbejdernes oplysningsforbund burde have sagt nejtak for nu at være høflig. Jeg var nu mest den lyttende til al diskussion, men det var heller ikke det ringeste. Jeg lærte at se mange ting fra mange sider og syntes selv, at jeg kunne skelne skidt fra kanel.

Lærerne var herlige mennesker, de forstod at lede skolen $\mathrm{i}$ en god demokratisk ånd, så alle fik lov at lufte deres meninger om tilværelsen, som den burde være og ikke være. Det var en god og belærende vinter, jeg tilbragte på højskolen, og jeg tog derfra mere selvbevidst, end da jeg kom til skolen. 
Efter at skoleopholdet var afsluttet til april, kom jeg straks tilbage til min læreplads, hvor man havde påbegyndt omlægning af produktionen fra mejeriartikler til køleanlæg og dermed beslægtede artikler. Arbejdet blev for mig ikke af lang varighed. Da det var en ny produktion, som der skulle sættes akkordpriser på, viste det sig, at der var stor forskel på, hvad fabrikanten og jeg vurderede min arbejdskraft til i kroner og ører, så jeg sagde farvel. Ikke mange dage efter havde jeg fået arbejde på Wittenborgs automatfabrikker i Odense.

$\mathrm{Da}$ jeg kom hjem for at fejre julen og nytåret hos mine forældre, fik jeg under opholdet, en henvendelse fra frabrikant Aage Gram, om jeg ville aflægge ham et besøg $i$ hans hjem for en personlig samtale. Jeg havde ingen anelse om, hvad samtalen skulle dreje sig om. Jeg var jo et høfligt menneske med god opdragelse, så jeg mødte frem, og jeg må sige, det blev en overraskelse. Jeg fik tilbud om at komme tilbage til firmaet. Jeg følte mig nok beæret og var vel heller ikke uimodtagelig for smiger, det kan jeg se efter nærmere omtanke.

Jeg mødte op 7. januar 1932 om morgenen ved arbejdstidens begyndelse. Forbavselse og forundring på værkstedet; men jeg fik en god velkomst. Det blev til 33 års uafbrudt virke i firmaet fra nævnte dato, og det blev gode år. Når de ikke fortsatte til min normale pensionsalder, skyldes det en stærkt tiltagende slidgigt.

Firmaet Brdr. Gram var inde i en ekspansion, efterhånden øgedes de ansatte $i$ tal, så værkstederne måtte udvides. Der var fremgang i produktion, nye konstruktioner befordrede større omsætning. Den drivende kraft i firmaet var fabrikant Aage Gram, bistået af en dygtig stab af teknikere og medarbejdere i alle led.

Jeg kom denne mand på nærmeste hold, idet jeg kort tid efter min tiltrædelse blev tillidsmand for mine kolleger på værkstedet. Jeg havde denne tillidspost gennem mange år, så jeg vil mene, at jeg er kompetent til at udtale mig om hans varemåde og både de positive og negative sider. Hans dygtighed og indsigt på mange områder kan ikke bestrides. Han hørte ikke til den grå masse, han var en mand, der brugte det indvendige af hovedet, tænkte mere frem end tilbage; men han kendte sandelig også sit eget værd. Det var en mand med enkle livsvaner og uden respekt for ydre prunk - sådan da -. Man havde det indtryk, at han godt ville betragtes som en ikke hvem som helst, hvad han bestemt heller ikke var; på den anden side kunne hans respekt for de underdanige være på et lille sted.

Vi var i en del år kun to tillidsmænd på fabrikken. Én for smede og maskinarbejdere og jeg for blikkenslagerne og kobbersmedene. Egent- 
lig var vi tre, den tredie havde vi to tillidsmænd egenmægtig valgt, og vedkommende var ikke af kød og blod. Den valgte var frk. Fornuft. Hvorfor vi havde valgt hunkønsbetegnelsen husker jeg ikke; men hun var altså i påkommende tilfælde anbragt mellem os to tillidsmænd af kød og blod. Hende spurgte vi til råds, når vi skulle tage stilling til taktik og fremgangsmåde ved forhandlingsbordet.

Dengang var demokrati og medbestemmelse på arbejdspladsen ikke opfundet, og forresten var ordet arbejdsklima heller ikke i ordbogen. Skulle en eller anden have snakket om arbejdsklima, ville man ganske simpelt have forbundet det med vejrliget, om det var koldt eller varmt, regn eller solskin, eller om temperaturen var passende til det arbejde, man udførte. Dette med demokrati og medbestemmelse lå ikke rigtig for fabrikanten, på disse områder kunne han være altmodisch; men det bedredes betydelig, efterhånden som udviklingen skred frem.

Man kan ikke påstå, at fabrikanten var en dreven taktiker ved forhandlingsbordet, han kendte ikke til at lægge en dæmper på sin udtryksmåde. Høflighedsformularer var for ham et ukendt begreb,

Anders M. Johnsen. Foto 1982.

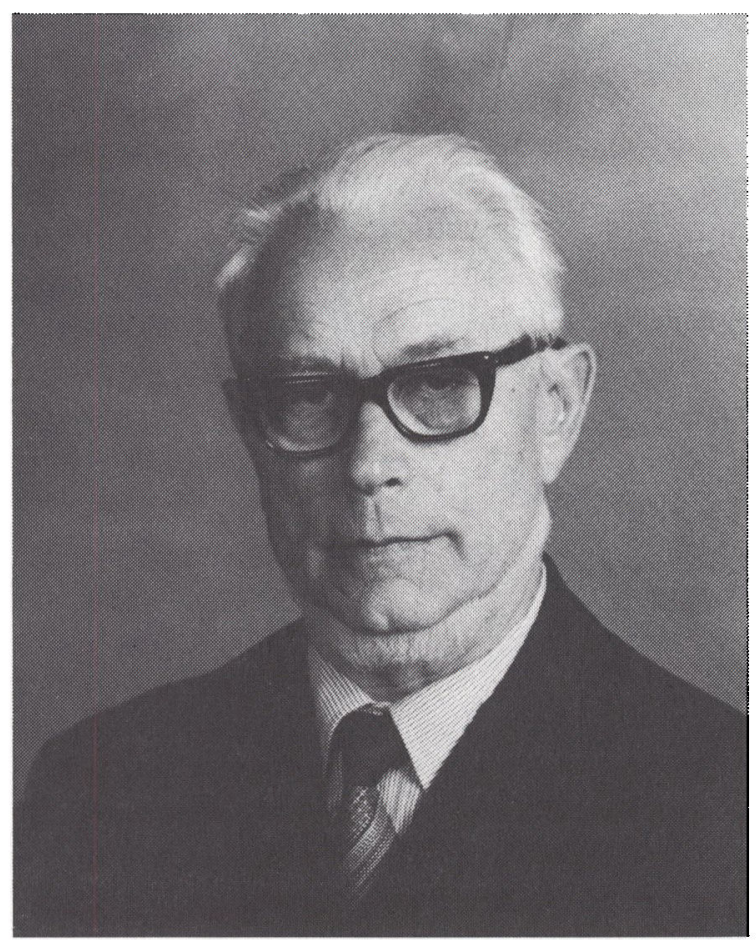


under alle tilfælde blev tillidsmændene ikke overøst med den slags ting. Hans meninger var uforbeholdne og uden dikkedarer. Mere end en gang har vi tillidsmænd fået at vide - hvad vi forresten godt vidste - at Brdr. Gram drev ikke fabrik for vore blå øjnes skyld, så til tider skulle der selvbeherskelse til for at opføre sig pænt ved forhandlingsbordet. Man fandt de svage sider ved modparten, og lærte taktikken, hvor der skulle slækkes, og hvor man skulle stå fast. Det skete, at vi to tillidsmænd af kød og blod måtte fratage frk. Fornuft stemmeret, når vi var blevet provokeret ved forhandlingsbordet og følte vor person gået for nær. I det store og hele var samarbejdet dog udmærket. Begge parter måtte forstå at føre en urban tone, for at det hele kunne fungere på en tilfredsstillende måde. Vi tillidsmænd måtte af og til veje og vurdere en stillingtagen ud fra mere end en synsvinkel, hvad til tider kunne være svært. Jeg mindes mine år som tillidsmand som gode og belærende, og jeg lærte Aage Gram at kende fra hans mange sider. Der er blevet sagt om ham, at han ikke var fri for magtsyge. Det var der nu ikke tale om; men det er vel sådan, at en mand, der rager op over middel og er en foregangsmand med initiativ, hvori der lægges kræfter og en god portion vilje, let bliver misforstået.

Jeg skal ikke afholde mig fra at sige, at jeg havde stor respekt for hans person, og hvad han fik udrettet her $i$ jordelivet. Et tilsagn fra ham var et tilsagn og et ord et ord, det kunne man stole på. Det rigtige og rammende blev nok sagt ved hans jordefærd, denne mand var mere respekteret end afholdt.

Jeg var fagligt engageret $i$ de fleste af mine aktive arbejdsår, og håber jeg har forvaltet de mig givne pund og talenter nogenlunde tilfredsstillende. Det politiske lå ikke rigtig for mig; men det kunne selvfølgelig ikke helt adskilles, så jeg må nok bare betragtes som en partitro stemme til Stauning. Jeg deltog i mange faglige kurser, og der blev tildelt mig mange opgaver af mine fagfæller, det var både en udfordring og en tillid, som jeg håber at have honoreret.

Det var travle ungdomsår, som jeg mindes med glæde, men jeg fik da også tid til, at finde mig én, som jeg fik lov at dele bord og seng med. Jeg indgik i 1938 ægteskab med boghandlermedhjælper Mimi Matthiesen; det blev til 40 år, vi fik lov at leve livet sammen. Året efter, næsten på årsdagen for vort bryllup fødte min kone en søn; men jeg havde bestemt også gjort mit til, at han kom til verden. Jeg var stolt af min faderværdighed, og det gav jeg blandt andet tilkende ved, at jeg kørte ham i barnevogn på offentlig gade og vej. Men søde børn - det vakte forundring og måske lidt forargelse i hele Vojens. Tænk, et mandfolk 
køre med barnevogn, det var en nyhed for hele byen, og jeg måtte høre mange skosende bemærkninger for denne handling. Borgerskabet kom over choket. Jeg var nok den første af unge fædre, der trillede barnevogn i Vojens; men jeg fik hurtigt efterfølgere.

I 1939 og de følgende 5 år kom igen et menneskeskabt ragnarok og en fortumlet verden vågnede op $\mathrm{i} 1945$.

Hvis man ikke var kommet $\mathrm{i}$ karambolage med den gregorianske tidsregning, kunne man faktisk have stillet året på nul. Verden var blevet helt forandret, og hvad den ikke var, blev den i de følgende år. Teknologien fejrede store triumfer. Normer, som før krigen var god latin, blev kastet over bord, moral, etik, autoritet og mange andre af livets forhold var blevet antikveret. Tiden havde givet det hele et andet udgangspunkt.

Jeg har mange ønsker for kommende slægter, der skal befolke denne lidende og stridende, men dog så skønne jord.

Mit første og største ønske skal være, at hadets evangelium må få meget trange kår, at alle jordens folkeslag må være velsignet med det daglige brød, og hver ud fra sit ståsted må få del i alt det rige, som kan berige et menneskes sind og dets liv og levned. 
